\title{
Hypoxia-Dependent Reactive Oxygen Species Signaling in the Pulmonary Circulation: Focus on Ion Channels
}

\author{
Florian Veit, ${ }^{1}$ Oleg Pak, Ralf P. Brandes, ${ }^{2}$ and Norbert Weissmann ${ }^{1}$
}

\begin{abstract}
Significance: An acute lack of oxygen in the lung causes hypoxic pulmonary vasoconstriction, which optimizes gas exchange. In contrast, chronic hypoxia triggers a pathological vascular remodeling causing pulmonary hypertension, and ischemia can cause vascular damage culminating in lung edema. Recent Advances: Regulation of ion channel expression and gating by cellular redox state is a widely accepted mechanism; however, it remains a matter of debate whether an increase or a decrease in reactive oxygen species (ROS) occurs under hypoxic conditions. Ion channel redox regulation has been described in detail for some ion channels, such as $\mathrm{Kv}$ channels or TRPC6. However, in general, information on ion channel redox regulation remains scant. Critical Issues and Future Directions: In addition to the debate of increased versus decreased ROS production during hypoxia, we aim here at describing and deciphering why different oxidants, under different conditions, can cause both activation and inhibition of channel activity. While the upstream pathways affecting channel gating are often well described, we need a better understanding of redox protein modifications to be able to determine the complexity of ion channel redox regulation. Against this background, we summarize the current knowledge on hypoxia-induced ROS-mediated ion channel signaling in the pulmonary circulation. Antioxid. Redox Signal. $22,537-552$
\end{abstract}

\section{Introduction}

$\mathbf{T}$ HE EFFECTS OF ALVEOLAR HYPOXIA on the pulmonary circulation can be divided into three phases: (i) the acute phase ( $30 \mathrm{~s}$ to $<20 \mathrm{~min}$ ), (ii) the sustained phase ( $>30$-min to hours-days), which by hypoxic pulmonary vasoconstriction (HPV) matches blood perfusion to alveolar ventilation under conditions of regional alveolar hypoxia (163), and (iii) the chronic phase, which is characterized by refractory vasoconstriction (78) and vascular remodeling with media hypertrophy inducing pulmonary hypertension (PH) (Fig. 1). Alveolar epithelial cells are usually exposed to $100 \mathrm{~mm} \mathrm{Hg}$ and rarely experience $\mathrm{O}_{2}$ levels less than $40 \mathrm{~mm} \mathrm{Hg}$ (133). Under conditions of generalized alveolar hypoxia, the acute and sustained phases also contribute to PH development. There is substantial evidence that these three phases are, in part, regulated by different mechanisms $(51,93,111,165$, 166). Although the endothelium alters this vasoconstriction via release of vasoactive substances, this response is exclusive for pulmonary arterial smooth muscle cells (PASMC) such as the effector cell type (66). Changes in oxygen $\left(\mathrm{O}_{2}\right)$ levels are known to be accompanied by alterations of reactive oxygen species (ROS) production in PASMC. This ROS production has been suggested to be a key mediator of hypoxia-dependent signaling (153). While the $\mathrm{O}_{2}$-sensing mechanisms are still unknown, several lines of evidence for both mitochondrial and NADPH oxidases as predominant ROS sources exist. Among the various systems capable of producing ROS in mammalian cells, the mitochondrial respiratory chain and NADPH oxidases have been shown to be involved in the regulation of HPV under acute hypoxia, as well as in cell proliferation, and media hypertrophy during

\footnotetext{
${ }^{1}$ Excellence Cluster Cardiopulmonary System (ECCPS), Universities of Giessen and Marburg Lung Center (UGMLC), German Center for Lung Research (DZL), Giessen, Germany.

${ }^{2}$ Excellence Cluster Cardiopulmonary System (ECCPS), University of Frankfurt, Giessen, Germany.
} 


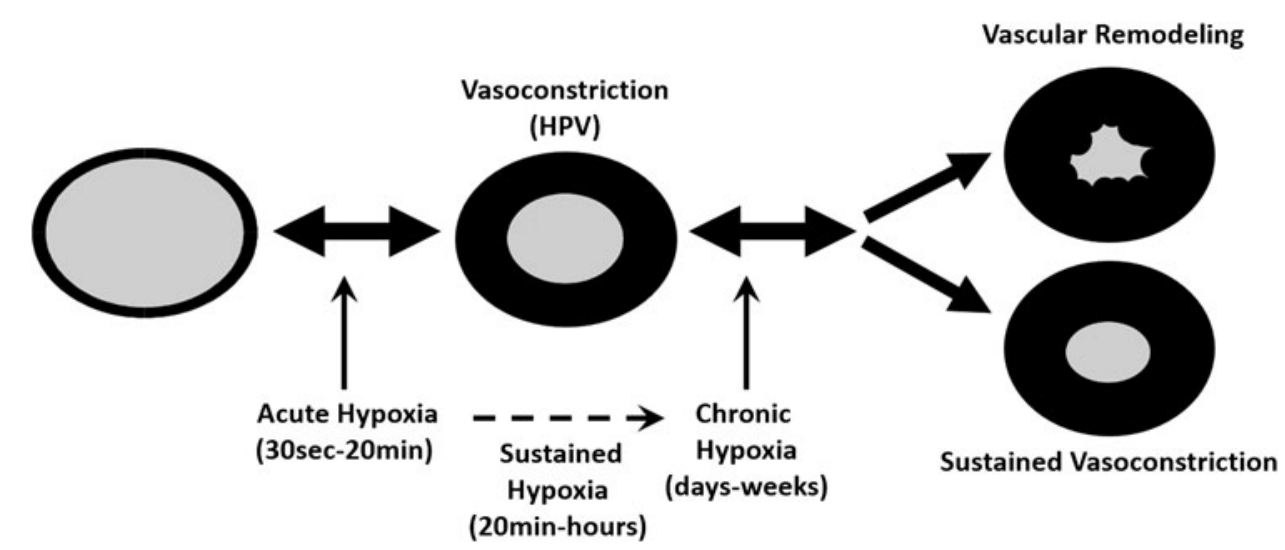

FIG. 1. Schematic illustration of the effects of alveolar hypoxia on the pulmonary circulation. The effects of alveolar hypoxia on the pulmonary circulation can be divided in three phases: (i) the acute ( 30 sec- 20 min), (ii) the sustained phase (20min-hours), and (iii) the chronic phase (days-weeks). Within seconds, acute hypoxia leads to hypoxic pulmonary vasoconstriction (HPV), matching blood perfusion to alveolar ventilation. Under conditions of generalized sustained and chronic alveolar hypoxia, this vasoconstriction is morphologically fixed by media hypertrophy (vascular remodeling) inducing pulmonary hypertension $(\mathrm{PH})$.

chronic hypoxia $(133,138)$. Although redox signaling has been suggested to be a crucial event in HPV and remodeling, there is a current debate as to whether an increase or a decrease in ROS triggers this process $(152,159)$. ROS can react with DNA, lipids, and polypeptides. However, only their effect on proteins endows them with specificity. High concentrations of ROS can cause a variety of amino-acid modifications (oxidation of thiol groups $[\mathrm{SH}]$, oxidation of arginine and lysine residues, or oxidation of methionine), molecular crosslinking, and trapping of proteins in multimolecular complexes. In contrast to the irreversible modifications that destroy protein function, physiological amounts of ROS can regulate protein function via specific interaction with amino acids (17).

The recognition of the involvement of ion channels in hypoxic events of the pulmonary vasculature uncovered Ltype calcium $\left(\mathrm{Ca}^{2+}\right)$ channels and potassium $\left(\mathrm{K}^{+}\right)$channels as important players $(8,146)$. Several other types of potassium and calcium channels were discovered, which also contribute to HPV and chronic hypoxia-induced PH (138, 160). These ion channels are highly sensitive to redox changes (109). In this regard, two antithetical models are currently discussed. The first model favors the closure of $\mathrm{Kv}$ channels mediated by a reduced mitochondrial ROS release, which activates vasoconstrictive, pro-proliferative, and antiapoptotic signaling cascades (6). This proposal is based on the opposing observations in terms of increased or decreased ROS production in the pulmonary circulation during hypoxia. There is also a debate about the potential sources of ROS production (i.e., mitochondria or NADPH oxidases) and their downstream targets (Fig. 2).

The second model proposes that an increase of ROS from mitochondria or NADPH oxidases triggers such events via different membrane channels, including $\mathrm{Kv}$-, transient receptor potential (TRP)-, and L-type $\mathrm{Ca}^{2+}$ channels and/or intracellular $\mathrm{Ca}^{2+}$ release (52) (Fig. 2). The discrepancies between the two models might be explained by studies that revealed differences in the basal oxidation state among the subcellular compartments. During acute hypoxia, the cytosol and intermembrane space showed increased ROS generation, whereas ROS production in the mitochondrial matrix was decreased (133). Under normoxic conditions, the mitochondrial complexes I and III produce small basal amounts of superoxide radicals (proportional to alveolar $\mathrm{PaO}_{2}$ ) (19). Superoxide from complex I and the Qi side of complex III enter the matrix, while superoxide formed on the Qo side of complex III goes to the intermembrane space and is then converted to hydrogen peroxide $\left(\mathrm{H}_{2} \mathrm{O}_{2}\right)$, which is able to pass the outer mitochondrial membrane and to enter the cytosol (133). Besides the mitochondrial respiratory chain, the ROS locally produced by the Nox family of NADPH oxidases during normoxia elicit a plethora of cellular responses required for physiological growth factor signaling $(21,22,86)$. However, under hypoxic conditions, increased $(52,133,152)$ and decreased $(5,6,156)$ ROS production during acute and chronic hypoxia has been described.

The determination of the pulmonary vascular tone by ion channels in response to hypoxia is widely accepted. Whether due to an increase of decrease of ROS, $\mathrm{Ca}^{2+}$ entry through Ltype channels, and release of calcium from the sarcoplasmic reticulum (SR) causes an increase in intracellular $\mathrm{Ca}^{2+}$, and initiates and maintains contraction of pulmonary vascular smooth muscle cells (VSMC) in response to hypoxia (151, 158).

Against this background, we, in this review, will focus on the role of redox regulation of ion channels during acute and chronic hypoxia. We are aware that we are not able to refer to all investigations which have been performed in this context. In addition, in a variety of instances, we refer also to nonpulmonary investigation if lung-specific literature is missing.

\section{Potassium Channels}

Potassium channels conduct $\mathrm{K}^{+}$ions across the cell membrane and are crucial for the pattern of action potentials (electric impulse formation), epithelial function, cell volume regulation, hormone secretion, and adjusting plasma membrane potential (59). The conduction follows the electrochemical gradient for $\mathrm{K}^{+}$, and these channels are extremely selective for $\mathrm{K}^{+}$(63). All known $\mathrm{K}^{+}$channels share the same 


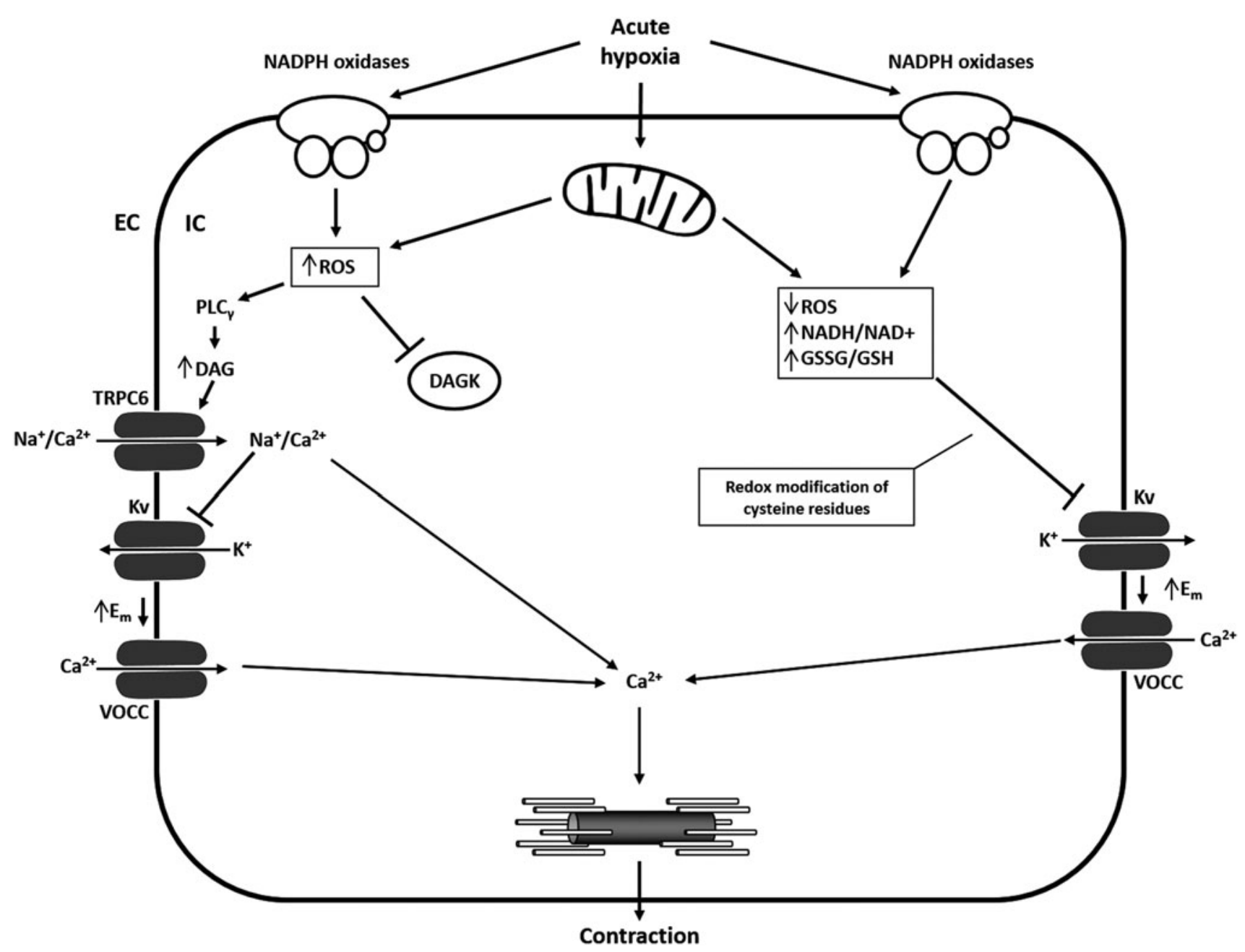

FIG. 2. Opposing models of the effect of acute hypoxia on ROS production and $\mathrm{Kv}$ channel regulation. With regard to the effect of acute hypoxia on PASMC depolarization, two models are discussed: The first model (right side) favors the closure of $\mathrm{Kv}$-channels mediated by a reduced ROS release (most likely by mitochondria) that activates vasoconstriction. The second model proposes that an increase of ROS from mitochondria and/or NADPH oxidases triggers such events via DAG-mediated activation of TRPC6, subsequent influx of $\mathrm{Na}^{+}$and $\mathrm{Ca}^{2+}$, and inhibition of $\mathrm{Kv}$ channels by $\mathrm{Na}^{+}$. DAG, diacylglycerol; DAGK, diacylglycerol kinase; EC, extracellular; $\mathrm{E}_{\mathrm{m}}$, membrane potential; IC, intracellular; Kv, voltagegated $\mathrm{K}^{+}$channels; PASMC, pulmonary arterial smooth muscle cells; ROS, reactive oxygen species; TRPC6, transient receptor potential channel 6 ; VOCC, voltage-operated $\mathrm{Ca}^{2+}$ channel.

structure of this very selective pore region. $\mathrm{K}^{+}$channels can be divided into five subcategories and differ mainly in the ways in which $\mathrm{K}^{+}$channels are gated open: (i) inward rectifiers (Kir), including classical Kir, G-protein-gated channels, ATP-sensitive $\mathrm{K}^{+}$channels $\left(\mathrm{K}_{\mathrm{ATP}}\right)$, and $\mathrm{K}^{+}$-transport channels; (ii) four transmembrane segments-2 pores $\left(\mathrm{K}_{2 \mathrm{P}}\right)$, including $\mathrm{pH}$, temperature, fatty acid, voltage, and membrane stretch-regulated channels; (iii) voltage-gated (Kv); (iv) the Slo family $\left(\mathrm{K}_{\mathrm{Ca}}\right)$, having a very large conductance and including the "big" $\mathrm{K}^{+}$channels (BK); and (v) $\mathrm{Ca}^{2+}$-activated SK family (SKCa), having a small conductance (SK channels) (59).

Four major types of $\mathrm{K}^{+}$channels have been identified in the pulmonary vasculature and the pulmonary arterial smooth muscle: (i) $\mathrm{Kv}$ channels, (ii) $\mathrm{K}_{\mathrm{Ca}}$ channels, (iii) $\mathrm{K}_{\mathrm{IR}}$ channels, and (iv) $\mathrm{K}_{2 \mathrm{P}}$ channels $(25,102)$. In PASMC, efflux of $\mathrm{K}^{+}$ after activation of $\mathrm{K}^{+}$channels leads to membrane hyperpolarization and, subsequently, vasodilation. In contrast, in- hibition of $\mathrm{K}^{+}$channels causes depolarization and vasoconstriction (32). Inhibition of $\mathrm{K}^{+}$channels and influx of $\mathrm{K}^{+}$(rather the reduction in $\mathrm{K}^{+}$conductance) was shown to initiate membrane depolarization, activation of voltageoperated $\mathrm{Ca}^{2+}$ channels (VOCCs), and vasoconstriction. In PASMC, this role has mainly been assigned to $\mathrm{Kv}$ and $\mathrm{K}_{2 \mathrm{P}}$ channels (105), while $\mathrm{K}_{\mathrm{Ca}}$ channels may be important in fetal or newborn animals $(34,120,126)$ and both $\mathrm{K}_{\mathrm{Ca}}$ and ATPsensitive potassium channels $\left(\mathrm{K}_{\mathrm{ATP}}\right)$ may modulate hypoxic depolarization in coronary arterial SMC $(38,39)$.

\section{Voltage-gated $\mathrm{K}^{+}$channels}

Although various types of $\mathrm{K}^{+}$channels are expressed in the pulmonary vasculature, much interest has been placed on the role of $\mathrm{Kv}$ channels, regarding the membrane potential (107, 171, 173), changes in pulmonary vascular tone (42, $119)$, and PASMC proliferation $(80,81,118) . \mathrm{Kv}$ channels 
represent the largest and most diverse family of $\mathrm{K}^{+}$channels. The family is composed by 40 genes: 36 genes of six transmembrane $\mathrm{K}^{+}$channels (KCNA [Kv1 family], KCNB [Kv2], $\mathrm{KCNC}[\mathrm{Kv} 3]$, and $\mathrm{KCND}$ [Kv4], KCNQ [Kv7], $\mathrm{KCNH}$ [Kv10, Kv11, and Kv12]), and a nonconducting group of four gating modulators (KCNF [Kv5], KCNG [Kv6], KCNV [Kv8], and KCNS [Kv9]). The functional channel is formed by four $\alpha$-subunits (tetrameric organization), with the pore lying in the axis. Each subunit has six transmembrane domains. $\mathrm{Kv}$ channels arrange as complexes of homo-tetramers or heterotetramers with many possible combinations $(59,127)$. Under acute hypoxia, the hypoxic stimulus triggers an inhibition of $\mathrm{Kv}$ channel activity in PASMC $(122,172)$. This effect has been described not only for PASMC but also for hypoxic-induced contraction in pulmonary vein smooth muscle cells (45).

In contrast, hypoxia neither inhibits $\mathrm{Kv}$ channel activity nor changes expression of $\mathrm{Kv}$ channels in systemic SMC $(119,147,149,172)$. Thus, Kv channels appear to be a hypoxic effector in the pulmonary circulation, but not in systemic SMC, conducting vasoconstriction.

Inhibition of $\mathrm{Kv}$ channels has also been suggested to be mediated by both decreased $(6,124,156,161)$ and increased (31, 101) ROS production from mitochondria and/or NADPH oxidases. In general, redox modification of cysteine residues is important for $\mathrm{Kv}$ activity. Sahoo et al. suggest that physiological levels of ROS trigger a positive feedback mechanism, which reduces $\mathrm{Kv}$ channel activity (131). Mittal et al. described a mechanism by which an Nox4derived increase in ROS production induces Kv channel current inhibition (101). Furthermore, Cogolludo et al. showed that activation of NADPH oxidase and the subsequent production of $\mathrm{H}_{2} \mathrm{O}_{2}$ are involved in the $\mathrm{Kv}$ channel inhibition and the contractile response induced by thromboxane receptor activation in rat pulmonary arteries (31).

In contrast, the complex I (NADH oxidoreductase) inhibitor rotenone and the flavoprotein inhibitor diphenyleneiodonium (DPI) were shown to inhibit HPV and Kv channel currents $(124,161)$. However, the effect of rotenone on mitochondrial respiration strongly depends on the concentration and was shown to trigger HPV, as well as to inhibit pulmonary vasoconstrictor responses (138). Rotenone-induced pulmonary vasoconstriction (using rotenone concentrations $>350 \mathrm{nM}$ ), which was similar to the degree of $\mathrm{HPV}$, has been attributed to nonselective effects rather than to altered ROS generation (138). Other inhibitors of the proximal and distal mitochondrial respiratory chain have also shown to elicit opposing affects regarding HPV (132).

While acute hypoxia acts via inhibition of $\mathrm{Kv}$ channel activity, during chronic hypoxia $\mathrm{K}^{+}$channel density and $\mathrm{Kv}$ channel protein expression (Kv1.5 and Kv2.1) is decreased, although a Kv current is still detectable (124). However, both induction and repression of $\mathrm{Kv}$ channel subunit expression under chronic hypoxia has been described $(44,61,91,147)$. Patch clamp studies showed that the hypoxic inhibition of the $\mathrm{Kv}$ current in PASMC is unchanged even after 2 days of ambient hypoxia, when HPV is already lost (169). However, after 3 weeks of chronic hypoxia, PASMC membrane potential was depolarized, Kv1.5 and Kv2.1 channel protein was decreased, and acute hypoxic inhibition of whole cell $\mathrm{K}^{+}$ current was lost (124). Other studies suggest Kv channel upregulation due to chronic impairment of the thioredoxin system under oxidative stress (pathophysiological ROS levels) (142). Further, interaction with pyridine nucleotides (76) and S-nitrosylation of Cys445 has been described (10).

\section{$\mathrm{Ca}^{2+}$-activated $\mathrm{K}^{+}$channels}

$\mathrm{Ca}^{2+}$-activated $\mathrm{K}^{+}\left(\mathrm{K}_{\mathrm{Ca}}\right)$ channels are subcategorized according to their conductance: large (BK), intermediate (IK), and small (SK). Here, we will focus on $\mathrm{BK}_{\mathrm{Ca}}$ channels. In contrast to the $\mathrm{BK}_{\mathrm{Ca}}$ channel, the role of $\mathrm{SK}_{\mathrm{Ca}}$ and $\mathrm{IK}_{\mathrm{Ca}}$ channels in VSMC is not well understood (168). $\mathrm{BK}_{\mathrm{Ca}}$ channels are ubiquitously expressed in VSMC and can be activated by changes in both membrane potential and intracellular $\mathrm{Ca}^{2+}$ concentration (79). These channels were shown to act as a negative-feedback mechanism in response to depolarization and increased cytosolic $\mathrm{Ca}^{2+}$ concentration during vasoconstriction. An increasing intracellular $\mathrm{Ca}^{2+}$ concentration was shown to decrease the $\mathrm{BK}_{\mathrm{Ca}}$ current and increase the $\mathrm{Kv}$ current (35). Thus, cytosolic $\mathrm{Ca}^{2+}$ levels not only play a major role regulating these channels but are also sensitive to voltage changes (58).

$\mathrm{BK}_{\mathrm{Ca}}$ channels are present in PASMC, but their role in whole cell $\mathrm{K}^{+}$currents depends on the species and varies in different pulmonary artery tree regions (94). Proximal segments contain a larger proportion of $\mathrm{K}_{\mathrm{Ca}}$-enriched PASMC, whereas distal segments contain more Kv-enriched PASMC (7, 96). In addition, it has been proposed that the hypoxic response due to $\mathrm{K}^{+}$channels changes as PASMC mature from fetal to neonatal and adult PASMC (33). It has been suggested that $\mathrm{K}_{\mathrm{Ca}}$ channel activity is prominent in hypoxiainduced fetal pulmonary vasodilation $(33,125)$. The contribution to the hypoxic response by $\mathrm{BK}_{\mathrm{Ca}}$ is still unclear. During acute hypoxia, $\mathrm{BK}_{\mathrm{Ca}}$ channel activity was attenuated in PASMC $(84,113,121)$, while $\mathrm{Ca}^{2+}$ release from SR increased $\mathrm{BK}_{\mathrm{Ca}}$ channel activity (18).

Since $\mathrm{Ca}^{2+}$ release in the SR is linked to the activation of large-conductance $\mathrm{K}_{\mathrm{Ca}}$ channels and membrane hyperpolarization (28), it remains unsolved whether acute hypoxiamediated $\mathrm{Ca}^{2+}$ release triggers membrane depolarization in PASMC. Not much is known about the redox regulation of $\mathrm{K}_{\mathrm{Ca}}$ channels in PASMC or the pulmonary vasculature of adults. At least for mouse lungs, it was shown that knockout of the functional essential BK channel alpha-subunit alters neither acute and sustained HPV nor chronic hypoxia-induced PH (130). $\mathrm{K}_{\mathrm{Ca}}$ channels were shown to be important in mediation of HPV in fetal lungs, but this was due to stimulation of a cyclic nucleotide-dependent kinase, resulting in $\mathrm{K}_{\mathrm{Ca}}$-channel activation, membrane hyperpolarization, and vasodilation (33).

The effect of ROS on $\mathrm{BK}_{\mathrm{Ca}}$ activity is, from our point of view, not conclusive and is mainly derived from nonpulmonary investigations. Figure 3 summarizes the proposed redox-regulation of $\mathrm{K}_{\mathrm{Ca}}$ channels. While the selective $\mathrm{BK}_{\mathrm{Ca}}$ channel inhibitor tetraethylammonium (TEA) (104) was shown to inhibit superoxide-induced vasodilation (154), it had no significant effect on open state probability of $\mathrm{BK}_{\mathrm{Ca}}$ channels (88). $\mathrm{H}_{2} \mathrm{O}_{2}$ has been reported to induce both activation and inhibition of $\mathrm{BK}_{\mathrm{Ca}}$ channel activity, depending on the experimental conditions $(135,143,144)$. While cysteine oxidation decreased the currents of large-conductance $\mathrm{Ca}^{2+}$ activated $\mathrm{K}^{+}$channels, methionine oxidation increased currents (143). Furthermore, $\mathrm{H}_{2} \mathrm{O}_{2}$ decreased activity of $\mathrm{BK}_{\mathrm{Ca}}$ channels by shifting the voltage sensitivity to a more positive direction (40). In VSMC, peroxynitrite was shown to inhibit 


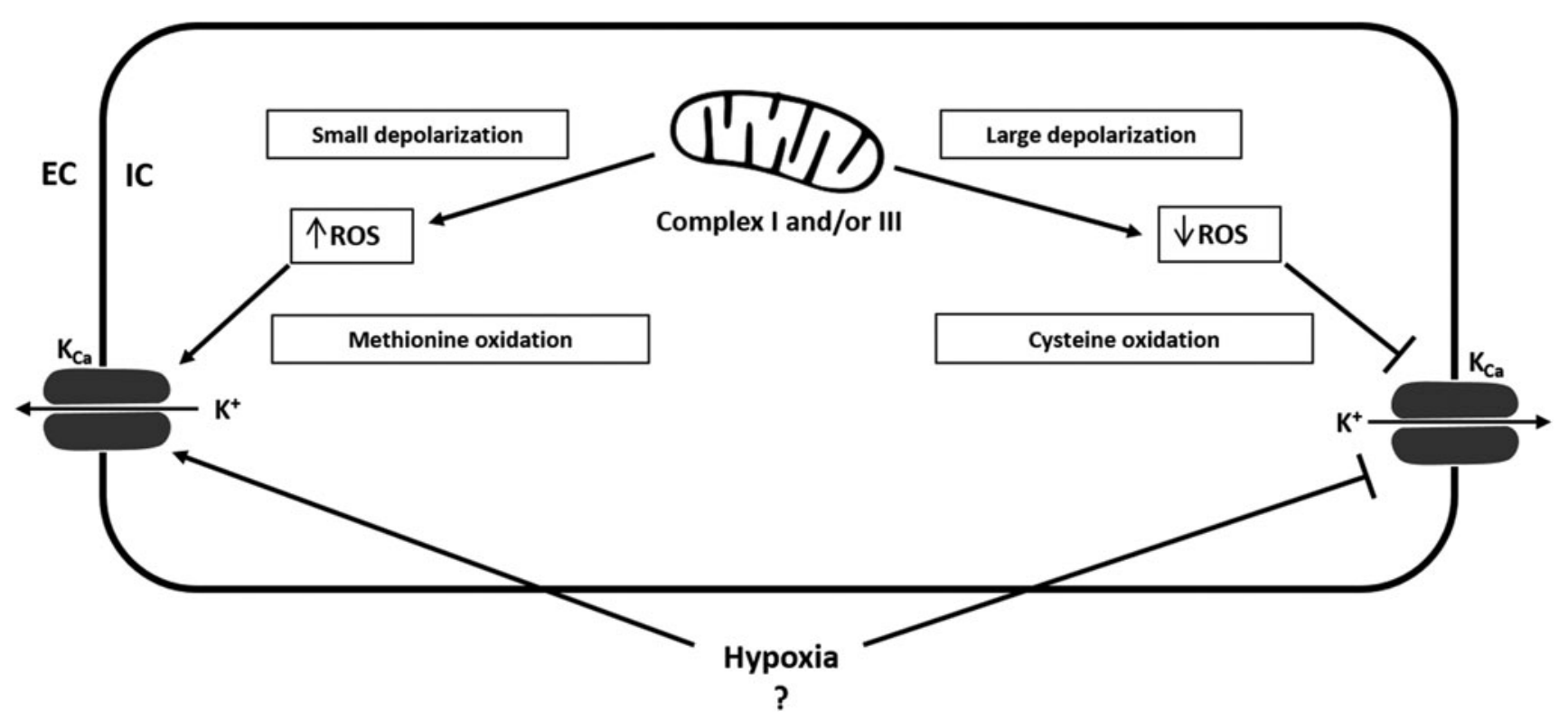

FIG. 3. Proposed redox regulation of $\mathbf{C a}^{2+}$-activated $\mathbf{K}^{+}$channels. Not much is known about the redox regulation of $\mathrm{K}_{\mathrm{Ca}}$ channels. Small mitochondrial depolarization causes elevated ROS production and activates transient $\mathrm{K}_{\mathrm{Ca}}$ currents. In contrast, large mitochondrial depolarization reduces ROS and inhibits transient $\mathrm{K}_{\mathrm{Ca}}$ currents. Hypoxia was shown to reduce $\mathrm{K}_{\mathrm{Ca}}$ channel activity, but the detailed effects of hypoxia on $\mathrm{K}_{\mathrm{Ca}}$ channels still remain largely unresolved. Oxidizing agents induce up- or down-regulation of $\mathrm{BK}_{\mathrm{Ca}}$ channel activity depending on the experimental condition. Cysteine oxidation decreases the currents of large conductance $\mathrm{Ca}^{2+}$-activated $\mathrm{K}^{+}$channels, whereas methionine oxidation increases currents. Redox regulation of $\mathrm{K}_{\mathrm{Ca}}$ channels most likely depends on the concentration of ROS or RNS, the oxidant/species, and the cell type. ? = Effects of hypoxia on $\mathrm{K}_{\mathrm{Ca}}$ channels are largely unresolved. EC, extracellular; IC, intracellular; $\mathrm{K}_{\mathrm{Ca}}$, $\mathrm{Ca}^{2+}$ activated $\mathrm{K}^{+}$channel; RNS, reactive nitrogen species.

$\mathrm{BK}_{\mathrm{Ca}}$ channel activity (24) by suppression of whole-cell $\mathrm{K}_{\mathrm{Ca}}$ current and reduction of open-state probability of single $\mathrm{K}_{\mathrm{Ca}}$ channels (88). In contrast, endothelial $\mathrm{BK}_{\mathrm{Ca}}$ channels did not react to peroxynitrite. The authors suggest that this behavior is due to an insensitivity of endothelial $\mathrm{BK}_{\mathrm{Ca}}$ channels to the interaction between superoxide and nitric oxide (NO) (43), which arises from the different $\beta$-subunit of $\mathrm{BK}_{\mathrm{Ca}}$ channels expressed in SMC and endothelial cells (168).

\section{ATP-sensitive $\mathrm{K}^{+}$channels}

$\mathrm{K}_{\mathrm{ATP}}$ are a subclass of inwardly rectifying $\mathrm{K}^{+}$channels (138), show little or no voltage dependence, and have low open probability under basal conditions. The channels consist of an octameric complex of four pore-forming inward rectifier $\mathrm{K}^{+}$channel subunits (Kir 6.1 or 6.2) and four sulfonylurea receptors (SURs) (3). Coexpression of these subunits produces two distinct channels, nucleotide diphosphatesensitive $\mathrm{K}^{+}$channels $\left(\mathrm{K}_{\mathrm{NDP}}\right)$ and $\mathrm{K}_{\mathrm{ATP}}(15)$. Coexpression of Kir 6.1 with SUR2B has been detected in human PASMC (37), and contribution to resting membrane potential in PASMC has been suggested. In contrast, inhibitors of $\mathrm{K}_{\mathrm{ATP}}$ did not increase normoxic pulmonary vascular resistance in adult mammals, suggesting that these channel types do not control basal pulmonary arterial tone. To date, there is no proposed role for $\mathrm{K}_{\mathrm{ATP}}$ channels in HPV and they have been suggested to be closed in the pulmonary arteries and not to be activated by the levels of hypoxia that cause a constriction (128).

As for $\mathrm{K}_{\mathrm{Ca}}$ channels, the redox regulation of $\mathrm{K}_{\mathrm{ATP}}$ channels in PASMC is not well described. In general, $\mathrm{K}_{\mathrm{ATP}}$ channels are gated by intracellular nucleotides, linking energy me- tabolism to membrane excitability. In tissues other than the lung, there is increasing evidence the $\mathrm{K}_{\mathrm{ATP}}$ channel activity is likely regulated by redox state $(12,13,82)$. Unfortunately, almost all redox dependent regulatory mechanisms were described in other tissues than the lung. Thus, we will not describe these mechanisms here.

\section{Two-pore-domain $\mathrm{K}^{+}$channels}

Two-pore-domain or $\mathrm{K}_{2 \mathrm{P}}$ channels contain four transmembrane domains and two pore domains. A dimer of two subunits forms a single pore and thus the functional channel (two pores in total). N- and C-Terminus is located in the cytosol. $\mathrm{K}_{2 \mathrm{P}}$ channels are selective to $\mathrm{K}^{+}$and are important for the regulation of the resting membrane potential (background $\mathrm{K}^{+}$channels), thereby regulating cellular excitability and $\mathrm{K}^{+}$permeability $(27,95,140)$. The regulation of $\mathrm{K}_{2 \mathrm{P}}$ channels is quite complex, as these channels respond to many stimuli, including $\mathrm{pH}$, stretch, temperature, fatty acids, $\mathrm{O}_{2}$ tension, sumoylation, phosphorylation, dephosphorylation, and osmolarity $(117,140)$. Due to the $\mathrm{K}^{+}$selectivity and the voltage-independent gating [TREK-1 is voltage gated when S348 is phosphorylated (92), and TASK-1 was shown to be voltage dependent in rabbit PASMC (62)], $\mathrm{K}_{2 \mathrm{P}}$ channels are well suited for mediating background $\mathrm{K}^{+}$currents.

$\mathrm{K}_{2 \mathrm{P}}$ comprise six subfamilies: TWIK, TREK, TASK, TASK-2, THIK, and TRESK channels (132). In the pulmonary vasculature expression of TASK-1, TASK-2, TREK-2, THIK-1, and TWIK-2 has been demonstrated (53). However, only for TASK-1 and TASK-2 (mainly TASK-1), involvement in a noninactivating background $\mathrm{K}^{+}$conductance has been shown, where hypoxia-induced inhibition of TASK-1 
contributed to PASMC depolarization $(47,108)$ and HPV $(53,57)$.

Since TASK-1 cannot sense $\mathrm{O}_{2}$ itself, the NADPH oxidase $\mathrm{NOX} 4$ has been suggested to be the $\mathrm{O}_{2}$-sensing partner modulating the $\mathrm{O}_{2}$ sensitivity of TASK-1. In HEK293 cells, hypoxia-induced activation of NOX4 inhibited TASK-1 activity (85). In this process, the heme moiety and FAD-binding domain were proposed to be responsible for the NOX4 regulation of TASK-1 (114). Further, in HeLa cells, TASK-1, TASK-3, and a TASK-1/3 heteromer were shown to be activated by $\mathrm{H}_{2} \mathrm{O}_{2}$. This effect was independent of the oxidation of-SH groups, suggesting that $\mathrm{H}_{2} \mathrm{O}_{2}$ acts directly on the channel protein.

In contrast, TREK-1, TREK-2, TALK-1, TASK-2, and TRESK did not respond to $\mathrm{H}_{2} \mathrm{O}_{2}$ treatment. Superoxide derived from a xanthine/xanthine oxidase mixture only affected TASK-2 activity in HeLa cells (112). It should be noted that $\mathrm{H}_{2} \mathrm{O}_{2}$ had no significant effect at concentrations till $16.3 \mathrm{mM}$, which is a rather unphysiological concentration (137) and might cause unspecific effects. Earlier, Kim et al. published conflictive results showing that $\mathrm{H}_{2} \mathrm{O}_{2}$ did not affect TASK-1, TASK-3, and TRAAK currents when the channels were expressed in CHO cells. However, TREK-2 was activated by $\mathrm{H}_{2} \mathrm{O}_{2}$, presumably as a response to $\mathrm{H}_{2} \mathrm{O}_{2}$-induced myosin light chain kinase (MLCK) activation (77). The different findings by Kim et al. might be explained by the much lower $\mathrm{H}_{2} \mathrm{O}_{2}$ concentration $(5 \mathrm{mM})$ and the different cell type used in their study and are partially supported by research published by Turner and Buckler (145). Their results show that hypoxia (and thus ROS) inhibits single channel activity of TASK-1 and TASK-2 in type-1 cells isolated from the carotid body.

\section{Calcium Channels}

Intracellular $\mathrm{Ca}^{2+}$ concentration is central for the regulation of vessel tone. During homeostasis, intracellular $\mathrm{Ca}^{2+}$ is $\sim 100 \mathrm{n} M$ intracellular and $1.6 \mathrm{~m} M$ extracellular (67). This huge concentration gradient between the intracellular and the extracellular $\mathrm{Ca}^{2+}$ concentration shows the importance of tightly controlled cellular $\mathrm{Ca}^{2+}$ homeostasis. $\mathrm{Ca}^{2+}$-permeable channels allow $\mathrm{Ca}^{2+}$ to enter into the cell through the membrane due to its electrochemical gradient. $\mathrm{Ca}^{2+}$ pumps transport $\mathrm{Ca}^{2+}$ against its concentration gradient, and the $\mathrm{Ca}^{2+}$ exchangers that can transport $\mathrm{Ca}^{2+}$ to the intra- or extracellular milieu, depending on the mode of action (109). The following channels coordinate cytosolic $\mathrm{Ca}^{2+}$ concentration in PASMC: (i) extracellular $\mathrm{Ca}^{2+}$ entry via VOCCs, (ii) receptor-operated cation channels (ROCs), and (iii) storeoperated channels (SOCs) activated by depletion of the SR (109). Alterations of the intracellular $\mathrm{Ca}^{2+}$ concentration play an important role in muscle contraction (skeletal, cardiac, and smooth muscle) and cell motility, neurotransmitter release, neuronal excitability, learning and memory, fertilization and development, cell proliferation, differentiation, apoptosis, and gene transcription. The $\mathrm{Ca}^{2+}$ influx is crucial for hypoxic constriction of the precapillary pulmonary arteries (136). The best characterized pathways of $\mathrm{Ca}^{2+}$ entry into PASMC are through VOCCs (regulated by the resting membrane potential) and TRP channels (TRPC; voltageindependent nonselective cation channels, SOCs and ROCs) (160). An increase of intracellular $\mathrm{Ca}^{2+}$ concentration in PASMC has been widely accepted to be a critical event for HPV (151). In the pulmonary vasculature, the acute hypoxic
$\mathrm{Ca}^{2+}$ release in PASMC is dependent to a lesser degree on VOCCs (inhibition attenuated hypoxic $\mathrm{Ca}^{2+}$ release by $30 \%$ ) and to a greater degree on other transmembrane channels such as TRPC (inhibition attenuated hypoxic $\mathrm{Ca}^{2+}$ release by $60 \%$ ) (141). These channels are mainly responsible for the sustained PASMC contraction associated with HPV and modulation of the pulmonary hypoxic response.

\section{Voltage-operated $\mathrm{Ca}^{2+}$ channels}

The cellular membrane potential of PASMC is largely regulated by $\mathrm{K}^{+}$channels. Inhibition of $\mathrm{K}^{+}$efflux (e.g., during hypoxia) causes depolarization of the cell. VOCCs are activated when the depolarization reaches a certain threshold, a mechanism that is also known as excitation-contraction coupling (23). Moreover, the discovery that inhibitors of Ltype channels suppress HPV led to the long-standing hypothesis that HPV is primarily caused by redox-mediated inhibition of delayed-rectifier $\mathrm{K}^{+}$channels, depolarization, and voltage-dependent $\mathrm{Ca}^{2+}$ entry $(97,157)$.

VOCCs are ubiquitously expressed in VSMC. Their subunits include $\alpha_{1}, \beta_{1}-\beta_{4}, \gamma_{1}-\gamma_{8}$, and $\alpha_{2} \delta_{1}-\alpha_{2} \delta_{3}$, each containing six transmembrane spanning domains (S1-S6) enclosed by $\mathrm{N}$ - and C-termini. Many of these subunits can co-assemble, causing the heterogeneity of VOCCs. The $\alpha_{1}$ subunit is the major subunit, containing the $\mathrm{Ca}^{2+}$-selective pore (loop between S5 and S6) and voltage sensor (S4), is essential for channel function, and contains sites for channel regulation via intracellular second messengers, toxins, and drugs. The combination of $\alpha_{1}$ subunits with different accessory subunits forms six functionally distinct subfamilies: the L-, N-, P/Q-, $\mathrm{R}-$, and T-type channels (26). These major subgroups of the VOCC family are expressed in many cell types and are responsible for various cellular functions, including muscle contraction, control of action potential, secretion, and gene expression (17). The dihydropyridine-sensitive, high-voltageactivated and slowly inactivating L-type and the low-voltageactivated, rapidly inactivating T-type channels were most extensively studied in VSMC.

L-type channels have been extensively studied in PASMC and play an important role in increasing cellular $\mathrm{Ca}^{2+}$ concentration during hypoxia (48). L-type channels are highvoltage-activated (167) and regulate excitation-contraction coupling (56). L-type channels were shown to be upregulated in chronic hypoxia-induced $\mathrm{PH}$ and associated with a $\mathrm{Ca}^{2+}$ dependent resistance (68). Compared with conduit arteries, the density of L-type calcium channels is two-fold higher in PASMC of the resistance arteries (48).

The other common $\mathrm{Ca}^{2+}$ channel in the pulmonary vasculature is the low-voltage-activated T-type channel (174). These channels are insensitive to common L-type channel blockers, and their physiological relevance is poorly characterized (83). In the pulmonary vasculature, expression and function of T-type channels is not well described and their electrophysiological properties need to be fully characterized. Recent studies have also suggested that T-type channels are important in the proliferation of human PASMC (129). Rtype currents have been shown to be activated by endothelin1 (16) and cause enhanced cerebral artery constriction during subarachnoid hemorrhage $(71,87)$.

While influx of $\mathrm{Ca}^{2+}$ into the PASMC of resistance arteries is enhanced by hypoxia, the influx into SMC of the 
conduit arteries is inhibited (like systemic arteries) $(48,49)$. As previously mentioned, the acute hypoxic $\mathrm{Ca}^{2+}$ release in SMC of the pulmonary resistance arteries is dependent to a lesser degree on VOCCs (inhibition attenuated hypoxic $\mathrm{Ca}^{2+}$ release by $30 \%$ ) and to a greater degree on other transmembrane channels such as TRPC (inhibition attenuated hypoxic $\mathrm{Ca}^{2+}$ release by 60\%) (141). Nevertheless, VOCCs were one of the first $\mathrm{Ca}^{2+}$ channels to be identified as redox sensitive. Oxidants affect VOCC activity, expression, trafficking, open time, and open probability. Cysteine residues in the poreforming $\alpha_{1}$-subunit are the molecular targets for ROS (98), and both activation and inhibition of channel activity by oxidation have been described $(64,69,175)$ (Fig. 4).

Although almost all studies were done on myocytes or cardiac L-type channels, it has been suggested that the mode of action of the redox regulation from other tissues and cells can probably be translated into VOCCs of PASMC (109). However, this assumption is challenged by observations describing different effects of hypoxia on $\mathrm{Ca}^{2+}$ influx into the PASMC of resistance arteries (enhanced by hypoxia), and on the influx of $\mathrm{Ca}^{2+}$ into SMC of the conduit arteries (inhibited by hypoxia) $(48,49)$. Furthermore, acute hypoxic inhibition of the pore-forming $\alpha_{1}$-subunit is known to mediate hypoxic arterial vasodilatation, but hypoxia was also shown to selectively increase the L-type $\mathrm{Ca}^{2+}$ channels in PC12 cells and cerebellar granule neurons. Thus, it remains questionable whether the redox regulation of VOCCs can be translated from one tissue to another.

Hudasek et al. reported that human cardiac L-type $\alpha 1$ subunits expressed in HEK 293 cells showed increased cur- rents after application of $100 \mu M \mathrm{H}_{2} \mathrm{O}_{2}$ in a voltage-dependent manner. Catalase treatment reduced these currents. In contrast, the NADPH oxidase inhibitors diphenylene iodonium and phenylarsine oxide had no effect on either basal $\mathrm{Ca}^{2+}$ currents or responses to hypoxia. The authors concluded that endogenous production of $\mathrm{H}_{2} \mathrm{O}_{2}$ regulates the $\alpha_{1}$-subunit, but neither suppression of $\mathrm{H}_{2} \mathrm{O}_{2}$ levels nor inhibition of NADPH oxidase was involved in $\mathrm{O}_{2}$-dependent regulation of the $\mathrm{Ca}^{2+}$ channel (70). The hypoxia-induced increase in functional L-type $\mathrm{Ca}^{2+}$ channel expression has been verified in a recombinant expression system (HEK-293 cell line stably expressing the human L-type $\alpha_{1}$-subunit). However, increased functional expression was attributed to hypoxia-induced alterations of $\alpha_{1}$-subunit trafficking (116). In general, generation of ROS is altered during acute and chronic hypoxia, and oxidation of $\mathrm{SH}$ groups by ROS decreased cardiac L-type $\mathrm{Ca}^{2+}$-currents $(54,55)$, whereas oxidation of $\mathrm{SH}$ groups by other oxidizing agents (DTNB) caused stimulation of $\mathrm{Ca}^{2+}$. currents in ventricular myocytes. Thus, the effect of oxidizing agents on L-type channels seems to depend on the species and the mode of action.

\section{Store- and receptor-operated $\mathrm{Ca}^{2+}$ channels}

Influx of $\mathrm{Ca}^{2+}$ across the plasma membrane can also be triggered by depletion of $\mathrm{Ca}^{2+}$ from the endoplasmic reticulum (ER) and the SR. This so-called store-operated $\mathrm{Ca}^{2+}$ entry is mediated by SOCs. Besides the inhibition of $\mathrm{K}^{+}$ channels due to oxidation of channel residues, specifically on Kv1.5 (9, 102), depolarization of PASMC in response to

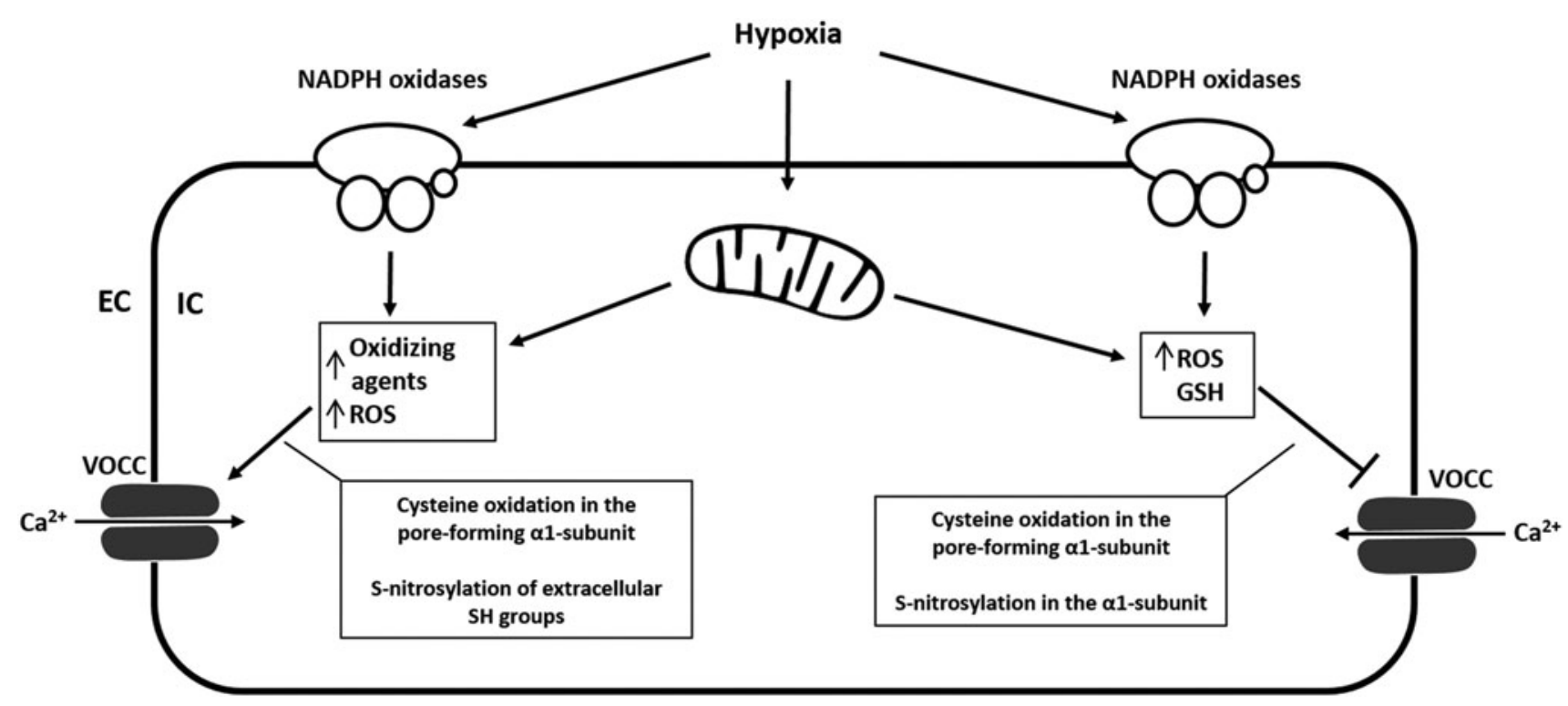

FIG. 4. Proposed redox regulation of VOCCs. VOCCs are activated when PASMC depolarization reaches a certain threshold (excitation-contraction coupling), but they are also redox sensitive. Cysteine residues in the pore-forming $\alpha_{1}$ subunit are the molecular targets for ROS, and both activation and inhibition of channel activity by oxidation have been described. Oxidants affect VOCC activity, expression, trafficking, open time, and open probability. Oxidation of SH groups by ROS decreases cardiac L-type $\mathrm{Ca}^{2+}$-currents, whereas oxidation of SH groups by other oxidizing agents (DTNB) causes stimulation of $\mathrm{Ca}^{2+}$-currents. The effect of oxidizing agents on VOCCs depends on the species and the mode of action. GSH inhibits the current, and cellular GSH levels are known to be reduced during hypoxia. S-nitrosylation of extracellular $\mathrm{SH}$ groups of the L-type $\mathrm{Ca}^{2+}$ channel increases currents, whereas S-nitrosylation in the $\alpha 1$-subunit decreases currents. Again, opposing findings might be explained by concentration- and species-dependent effects of ROS or RNS. DTNB, Ellman's reagent [5,5'-dithiobis-(2-nitrobenzoic acid)]; GSH, glutathione; SH, sulfhydryl group. 


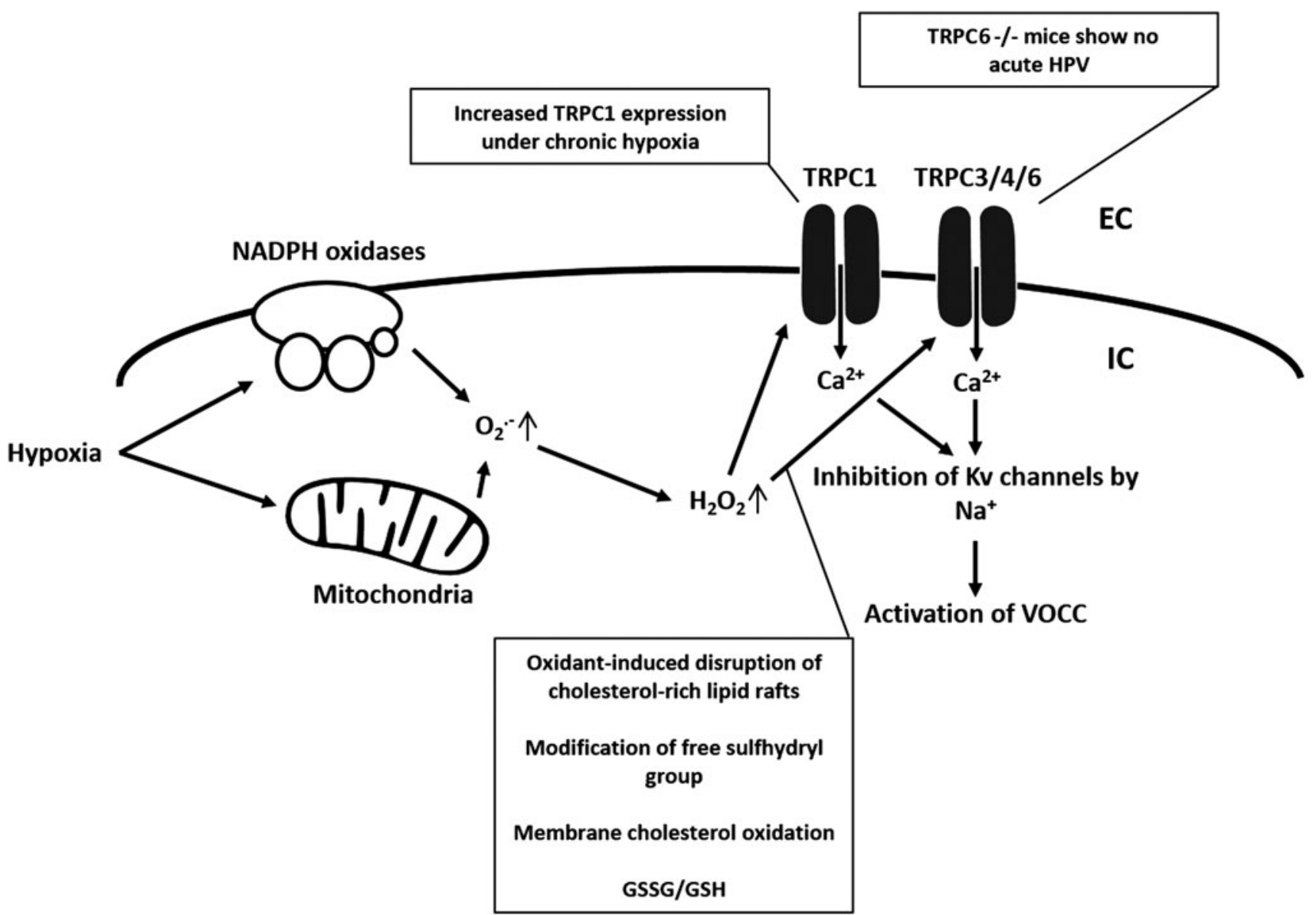

FIG. 5. Speculative redox regulation of TRPC3/4 and TRPC1 containing channels. TRPC $3 / 4$ are regulated by ROS, and TRPC3/4 containing channels can be activated in the presence of oxidants. ROS induce disruption of cholesterol-rich lipid rafts and membrane cholesterol oxidation, which has been suggested to activate TRPC $3 / 4$ containing channels. TRPC1 was shown to play an important role during vascular remodeling in chronic hypoxia-induced PH. Similar mechanisms as for TRPC3/4 might apply for the redox regulation of TRPC1. Although an activation of TRPC3/4 and TRPC1 (similar to TRPC6) by PLC and PLC-mediated hydrolysis of membrane-bound PIP cannot be excluded, the mechanism of oxidative stress-mediated TRPC3 activation does not involve PIP hydrolysis. The role of PLC in TRPC1 activation has not yet been addressed. GSSG, glutathione disulfide.

hypoxia has been shown to be initiated by a number of other mechanisms by which hypoxia could lead to inhibition of these and other $\mathrm{Kv}$ channels. These mechanisms include elevation of cytosolic $\mathrm{Ca}^{2+}$ concentration owing to $\mathrm{Ca}^{2+}$ release from stores $(73,121)$, and there is mounting evidence that hypoxiainduced depolarization of PASMC is at least partially due to activation of SOCs $(1,148,155)$. Activation of membrane receptors by ligand binding, diacylglycerol (DAG), and protein kinase $\mathrm{C}$ (PKC) can stimulate ROCs, causing $\mathrm{Ca}^{2+}$ influx and $\mathrm{Na}^{+}$efflux. Activation of $\mathrm{Na}^{+}$influx via nonselective cation channels as a result of either $\mathrm{Ca}^{2+}$ store depletion by SOCs or activation of a receptor- $\mathrm{G}$ protein-second messenger pathway by ROCs has been shown to be an important primary cause of depolarization and subsequent voltage-gated $\mathrm{Ca}^{2+}$ entry in PASMC $(134,148,155)$. In the vasculature in general, TRPC are capable of forming functional ROCs and SOCs (150).

Similar to VOCC, TRPC are a part of the superfamily of six transmembrane spanning cation channels, but lack the voltage sensitivity (voltage independent). TRPC are nonselective cation channels, but carry predominantly $\mathrm{Ca}^{2+}$ ions (110). In the pulmonary vasculature, several subtypes of have been identified according to their mechanism of activation and presence of regulatory domains in the $\mathrm{N}$ - and C-termini. These subtypes include the classical or canonical TRP (TRPC1-TRPC7), vanilloid-receptor-related TRP (TRPV1TRPV4), and melastatin-related TRP (TRPM1-TRPM8) channels (115). In VSMC, more than 10 TRP isoforms have been detected. However, TRPC1, TRPC4, and TRPC6 protein expression was shown to be higher in the distal pulmonary artery than in the proximal pulmonary artery, correlating with changes in cytosolic $\mathrm{Ca}^{2+}$ concentration occurring during HPV (89), and TRPC1 was further shown to play an important role in pulmonary vascular remodeling underlying the development of hypoxia-induced PH (93). TRPC6 is highly expressed in lung tissue as well as in pulmonary and VSMC and endothelial cells (41). In TRPC6 ${ }^{-/-}$mice, the acute phase of HPV is completely absent, while the sustained phase is not significantly affected (162) (Fig. 5). TRPC6 and TRPC3 were the first ion channels shown to be activated by DAG (Hofmann 1998). Under normoxia, DAG is localized in the cytoplasm. Under hypoxic conditions, DAG translocates to the plasma membrane gating TRPC6 (162). 


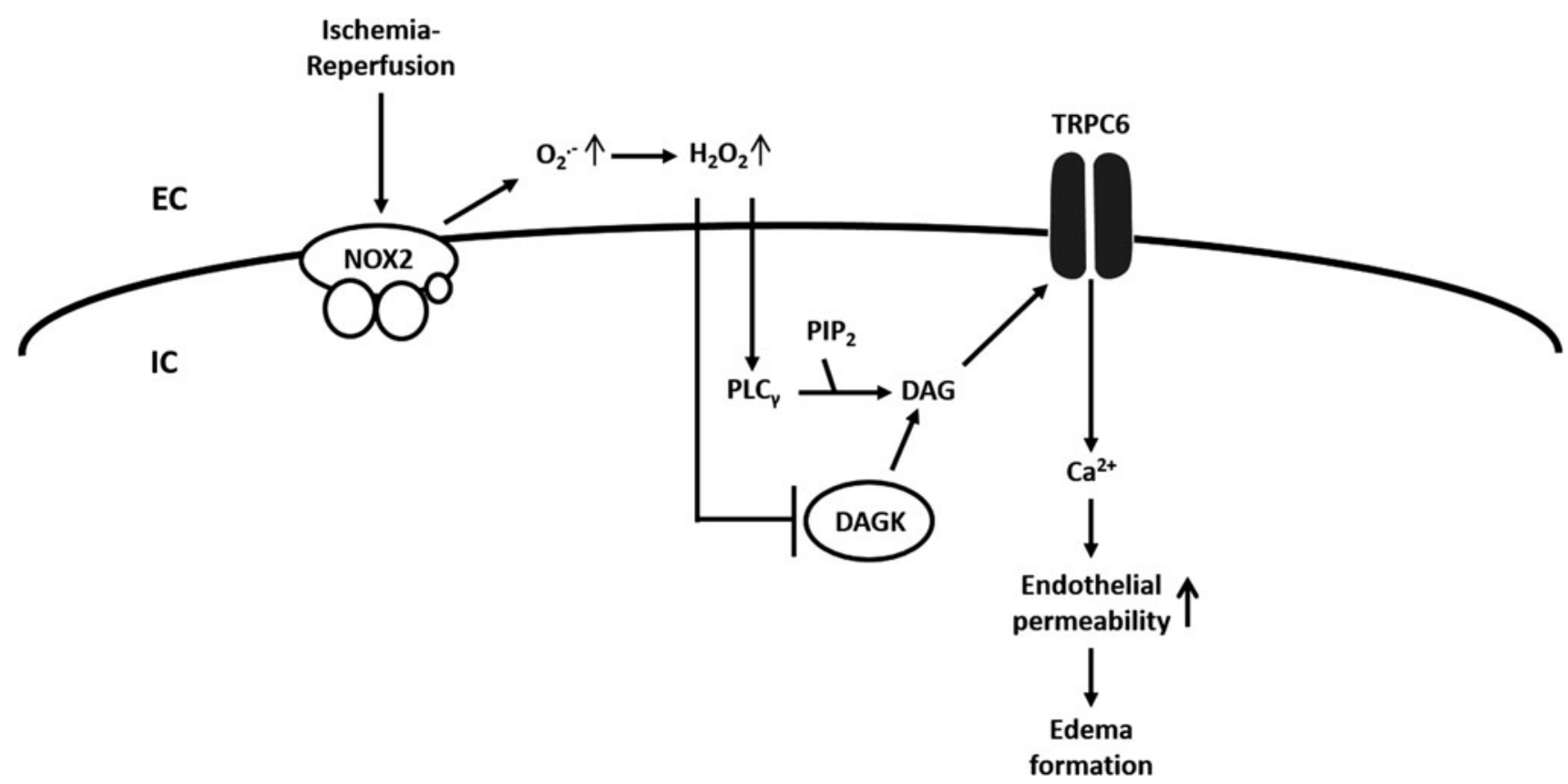

FIG. 6. Hypothesized role of TRPC6 in lung ischemia-reperfusion injury. In an animal model of LIRE, opening of TRPC6 in pulmonary vascular endothelial cells and subsequent $\mathrm{Ca}^{2+}$ influx was triggered by endothelial Nox2-derived production of superoxide, activation of phospholipase $\mathrm{C}-\gamma$, inhibition of DAG kinase (DAGK), accumulation of DAG, and DAG-mediated activation of TRPC6. In this model, $\mathrm{H}_{2} \mathrm{O}_{2}$ re-enters the cell (extracellular loop), activates PLC $\gamma$, and inactivates DAGK. $\mathrm{H}_{2} \mathrm{O}_{2}$, hydrogen peroxide; LIRE, lung ischemia-reperfusion-induced edema; Nox2, NADPH oxidase 2; $\mathrm{PIP}_{2}$, phosphatidylinositol 4,5-bisphosphate; PLC $\gamma$, phospholipase C- $\gamma$.

Possibly, the DAG translocation is triggerd by increased ROS as an investigation in an animal model of lung ischemia-reperfusion (I/R)-induced edema showed that TRPC6 in endothelial cells can be activated by endothelial Nox2-derived production of superoxide during the hypoxic phase of I/R with subsequent activation of phospholipase C- $\gamma$, and inhibition of DAG kinase, (164). According to this concept, superoxide is converted to $\mathrm{H}_{2} \mathrm{O}_{2}$, which, via an extracellular loop, triggers the TRPC6 response (164) (Fig. 6). As previously mentioned, TRPC are nonselective cation channels. Thus, we further speculate that sodium entry through TRPC6 and increasing sub-sarcolemmal $\mathrm{Na}^{+}$-concentrations inhibits $\mathrm{Kv}$-channels and activates L-type $\mathrm{Ca}^{2+}$ channels (50) (Fig. 2).

It is well known that increased ROS generation can lead to $\mathrm{Ca}^{2+}$ release from intracellular stores as well as to $\mathrm{Ca}^{2+}$ entry across the plasma membrane (103). Especially in nonexcitable cells (e.g., endothelial cells) (106), although pulmonary microvascular endothelial cells express a functional voltage-gated T-type calcium channel (174), the major $\mathrm{Ca}^{2+}$ entry pathways are through SOCs and ROCs. TRPC7 (TRPM2) and TRPC3/TRPC4 have been shown to be regulated by ROS in endothelium (30). TRPC7 is no longer considered a TRPC family member (30). TRPC3/4 containing channels were shown to be activated and contributing to endothelial cell depolarization in the presence of oxidants (14) and to be regulated by oxidative stress (60) by oxidantinduced disruption of cholesterol-rich lipid rafts.

Similar to TRPC6, TRPC3 activation is regulated by Ctype phospholipase (PLC) and by PLC-mediated hydrolysis of membrane-bound PIP. However, the mechanism underlying oxidative stress-mediated TRPC3 activation does not involve PIP hydrolysis. It has been speculated that membrane cholesterol oxidation by ROS might be the signaling event that activates TRPC3 (60). Poteser et al. concluded that TRPC 3 and TRPC4 contribute subunits to the redox-sensitive channel. The identity of the other two subunits is unclear (123). The role of PLC in TRPC1 activation has not yet been addressed. SOCs were also shown to be indirectly regulated by cellular redox status through a nonselective cation channel that is covalently modified by glutathione disulfide (GSSG), an antioxidant molecule. It has also been suggested that SOCs may itself be a direct target of GSSG (thus of the cellular redox state) or some other ROS/reactive nitrogen species (30). In general, not much is known about redox regulation of SOC entry channels in the lung. Acute hypoxia (i.e., more ROS) was shown to enhance capacitative $\mathrm{Ca}^{2+}$ entry through SOCs in distal PASMC with subsequent depolarization and activation of VOCCs, suggesting a role for SOCs in HPV (148). Further, SOC and VOCC antagonists inhibited PASMC contraction during hypoxia as well as SOC-dependent activation of VOCCs (155). A hypothesis about ROS-dependent TRPC1 and TRPC3/4 regulation is given in Figure 5.

It should be noted that TRPM2, TRPM7, TRPC5, and TRPV1 are activated by $\operatorname{ROS}(2,72,170)$. In the case of TRPC5, TRPV1, and TRPA1, activation was triggered via oxidation of a free cysteine sulfhydryl group $(139,170)$. It remains to be determined whether these findings are consistent with other TRPC or TRPC in the lung.

\section{Conclusion}

Redox regulation of ion channel expression and gating under hypoxia and hypoxia-associated conditions, as well as 
under other conditions with an impact on the cellular redox state is a widely accepted mechanism. Direct reversible effects of ROS on ion channels include, but are not restricted to, oxidation of thiol groups, oxidation of arginine and lysine residues, and oxidation of methionine. Indirect reversible effects comprise, for example, alterations of GSH levels, activation of PLC (DAG), activation of PKC, and alterations of cytosolic $\mathrm{Ca}^{2+}$ levels.

Although our understanding of ion channel redox regulation is quite detailed for some ion channels ( $\mathrm{Kv}$ channels, TRPC6), it remains generally scant. In addition to the the debate of increased or decreased ROS production during hypoxia, we need to understand why different oxidants under different conditions can cause both activation and inhibition of channel activity. According to the available literature, the ROS from an identical source can act on different amino-acid residues of an ion channel, thereby mediating opening or closing of the channel.

At the moment, most of the described redox regulatory mechanisms of ion channels are based on speculations and extrapolation of a few known redox regulatory mechanisms. While the upstream pathways affecting channel gating are often well described, the effects of ROS on the individual proteins of the pathways remain mostly unknown. One issue is to get a better understanding of redox protein modifications to be able to determine the complexity of ion channel redox regulation. It will be crucial to decipher how ROS are orchestrated and what role the spatial distribution of ROS plays in this regard. It has become obvious that physiological redox signaling is confined both spatially and temporally in subcellular compartments and microdomains. The redox status of a cell is not necessarily a global imbalance of oxidants and reducing molecules, but rather the net status of the redox status in different cellular compartments.

As the most redox-active compartment in the cell, mitochondria are a prominent site for ROS production $(20,75)$. Although mitochondria have a very high antioxidative capacity, excessive ROS release can cause a variety of disorders (74). The cytoplasm can also represent a subcellular compartment. Stimulation of the plasma membrane can trigger oxidation of specific proteins in the cytosol without affecting other organelles (100). Other redox active compartments are the nucleus, the ER lumen (36), peroxisomes (46), endosomes, and lysosomes (11). Within these compartments, ROS in microdomain generation can also be very diverse (90). Against this background, NADPH oxidases, another prominent cellular ROS source, have been shown to be expressed in such ROS microdomains [e.g., in caveolae (65) and endosomes (99)]. It has even been suggested that single Nox isoforms (Nox1) can have multiple signaling effects by occupying different microdomains within the cell $(4,29)$.

\section{References}

1. Aaronson PI, Robertson TP, Knock GA, Becker S, Lewis TH, Snetkov V, and Ward JP. Hypoxic pulmonary vasoconstriction: mechanisms and controversies. J Physiol 570: 53-58, 2006.

2. Aarts M, Iihara K, Wei WL, Xiong ZG, Arundine M, Cerwinski W, MacDonald JF, and Tymianski M. A key role for TRPM7 channels in anoxic neuronal death. Cell 115: 863-877, 2003.
3. Aguilar-Bryan L, Nichols CG, Wechsler SW, Clement JP, 4th, Boyd AE, 3rd, Gonzalez G, Herrera-Sosa H, Nguy K, Bryan J, and Nelson DA. Cloning of the beta cell highaffinity sulfonylurea receptor: a regulator of insulin secretion. Science 268: 423-426, 1995.

4. Al Ghouleh I and Pagano PJ. Endosomal ClC-3 and Nox1: moving marksmen of redox signaling? Arterioscler Thromb Vasc Biol 31: 240-242, 2011.

5. Archer $\mathrm{S}$ and Michelakis E. The mechanism(s) of hypoxic pulmonary vasoconstriction: potassium channels, redox $\mathrm{O}(2)$ sensors, and controversies. News Physiol Sci 17: 131-137, 2002.

6. Archer SL, Gomberg-Maitland M, Maitland ML, Rich S, Garcia JG, and Weir EK. Mitochondrial metabolism, redox signaling, and fusion: a mitochondria-ROS-HIF1alpha-Kv1.5 O2-sensing pathway at the intersection of pulmonary hypertension and cancer. Am J Physiol Heart Circ Physiol 294: H570-H578, 2008.

7. Archer SL, Huang JM, Reeve HL, Hampl V, Tolarova S, Michelakis E, and Weir EK. Differential distribution of electrophysiologically distinct myocytes in conduit and resistance arteries determines their response to nitric oxide and hypoxia. Circ Res 78: 431-442, 1996.

8. Archer SL, London B, Hampl V, Wu X, Nsair A, Puttagunta L, Hashimoto K, Waite RE, and Michelakis ED. Impairment of hypoxic pulmonary vasoconstriction in mice lacking the voltage-gated potassium channel Kv1.5. FASEB J 15: 1801-1803, 2001.

9. Archer SL, Souil E, Dinh-Xuan AT, Schremmer B, Mercier JC, El Yaagoubi A, Nguyen-Huu L, Reeve HL, and Hampl V. Molecular identification of the role of voltagegated $\mathrm{K}+$ channels, Kv1.5 and Kv2.1, in hypoxic pulmonary vasoconstriction and control of resting membrane potential in rat pulmonary artery myocytes. J Clin Invest 101: 2319-2330, 1998.

10. Asada K, Kurokawa J, and Furukawa T. Redox- and calmodulin-dependent S-nitrosylation of the KCNQ1 channel. J Biol Chem 284: 6014-6020, 2009.

11. Austin CD, Wen X, Gazzard L, Nelson C, Scheller RH, and Scales SJ. Oxidizing potential of endosomes and lysosomes limits intracellular cleavage of disulfide-based antibody-drug conjugates. Proc Natl Acad Sci U S A 102: 17987-17992, 2005.

12. Avshalumov MV, Chen BT, Koos T, Tepper JM, and Rice ME. Endogenous hydrogen peroxide regulates the excitability of midbrain dopamine neurons via ATPsensitive potassium channels. J Neurosci 25: 4222-4231, 2005.

13. Avshalumov MV and Rice ME. Activation of ATP-sensitive $\mathrm{K}+(\mathrm{K}(\mathrm{ATP}))$ channels by $\mathrm{H} 2 \mathrm{O} 2$ underlies glutamate-dependent inhibition of striatal dopamine release. Proc Natl Acad Sci U S A 100: 11729-11734, 2003.

14. Balzer M, Lintschinger B, and Groschner K. Evidence for a role of Trp proteins in the oxidative stress-induced membrane conductances of porcine aortic endothelial cells. Cardiovasc Res 42: 543-549, 1999.

15. Beech DJ, Zhang H, Nakao K, and Bolton TB. K channel activation by nucleotide diphosphates and its inhibition by glibenclamide in vascular smooth muscle cells. $\mathrm{Br} J$ Pharmacol 110: 573-582, 1993.

16. Bkaily G, Naik R, Jaalouk D, Jacques D, Economos D, D'Orleans-Juste P, and Pothier P. Endothelin-1 and insulin activate the steady-state voltage dependent R-type $\mathrm{Ca} 2+$ channel in aortic smooth muscle cells via a pertussis toxin 
and cholera toxin sensitive G-protein. Mol Cell Biochem 183: 39-47, 1998.

17. Bogeski I, Kappl R, Kummerow C, Gulaboski R, Hoth M, and Niemeyer BA. Redox regulation of calcium ion channels: chemical and physiological aspects. Cell Calcium 50: 407-423, 2011.

18. Bonnet P, Vandier C, Cheliakine C, and Garnier D. Hypoxia activates a potassium current in isolated smooth muscle cells from large pulmonary arteries of the rabbit. Exp Physiol 79: 597-600, 1994.

19. Bonnet S, Michelakis ED, Porter CJ, Andrade-Navarro MA, Thebaud B, Bonnet S, Haromy A, Harry G, Moudgil R, McMurtry MS, Weir EK, and Archer SL. An abnormal mitochondrial-hypoxia inducible factor-1alpha-Kv channel pathway disrupts oxygen sensing and triggers pulmonary arterial hypertension in fawn hooded rats: similarities to human pulmonary arterial hypertension. Circulation 113: 2630-2641, 2006.

20. Boveris A and Chance B. The mitochondrial generation of hydrogen peroxide. General properties and effect of hyperbaric oxygen. Biochem J 134: 707-716, 1973.

21. Brandes RP, Weissmann N, and Schroder K. Nox family NADPH oxidases in mechano-transduction: mechanisms and consequences. Antioxid Redox Signal 20: 887-898, 2014.

22. Brandes RP, Weissmann N, and Schroder K. Redox-mediated signal transduction by cardiovascular Nox NADPH oxidases. J Mol Cell Cardiol, 2014: 73:70-79.

23. Brayden JE and Nelson MT. Regulation of arterial tone by activation of calcium-dependent potassium channels. Science 256: 532-535, 1992.

24. Brzezinska AK, Gebremedhin D, Chilian WM, Kalyanaraman B, and Elliott SJ. Peroxynitrite reversibly inhibits $\mathrm{Ca}(2+)$-activated $\mathrm{K}(+)$ channels in rat cerebral artery smooth muscle cells. Am J Physiol Heart Circ Physiol 278: H1883-H1890, 2000.

25. Burg ED, Remillard CV, and Yuan JX. Potassium channels in the regulation of pulmonary artery smooth muscle cell proliferation and apoptosis: pharmacotherapeutic implications. Br J Pharmacol 153 Suppl 1: S99-S111, 2008.

26. Catterall WA, Perez-Reyes E, Snutch TP, and Striessnig J. International Union of Pharmacology. XLVIII. Nomenclature and structure-function relationships of voltage-gated calcium channels. Pharmacol Rev 57: 411-425, 2005.

27. Chemin J, Patel A, Duprat F, Zanzouri M, Lazdunski M, and Honore E. Lysophosphatidic acid-operated $\mathrm{K}+$ channels. J Biol Chem 280: 4415-4421, 2005.

28. Cheranov SY and Jaggar JH. Sarcoplasmic reticulum calcium load regulates rat arterial smooth muscle calcium sparks and transient $\mathrm{K}(\mathrm{Ca})$ currents. $J$ Physiol 544: 71-84, 2002.

29. Chu X, Filali M, Stanic B, Takapoo M, Sheehan A, Bhalla R, Lamb FS, and Miller FJ, Jr. A critical role for chloride channel-3 (CIC-3) in smooth muscle cell activation and neointima formation. Arterioscler Thromb Vasc Biol 31: 345-351, 2011.

30. Cioffi DL. Redox regulation of endothelial canonical transient receptor potential channels. Antioxid Redox Signal 15: 1567-1582, 2011.

31. Cogolludo A, Frazziano G, Cobeno L, Moreno L, Lodi F, Villamor E, Tamargo J, and Perez-Vizcaino F. Role of reactive oxygen species in $\mathrm{Kv}$ channel inhibition and vasoconstriction induced by TP receptor activation in rat pulmonary arteries. Ann N Y Acad Sci 1091: 41-51, 2006.
32. Coppock EA, Martens JR, and Tamkun MM. Molecular basis of hypoxia-induced pulmonary vasoconstriction: role of voltage-gated $\mathrm{K}+$ channels. Am J Physiol Lung Cell Mol Physiol 281: L1-L12, 2001.

33. Cornfield DN, Reeve HL, Tolarova S, Weir EK, and Archer S. Oxygen causes fetal pulmonary vasodilation through activation of a calcium-dependent potassium channel. Proc Natl Acad Sci U S A 93: 8089-8094, 1996.

34. Cornfield DN, Saqueton CB, Porter VA, Herron J, Resnik E, Haddad IY, and Reeve HL. Voltage-gated $\mathrm{K}(+)$ channel activity in ovine pulmonary vasculature is developmentally regulated. Am J Physiol Lung Cell Mol Physiol 278: L1297-L1304, 2000.

35. Cox RH and Rusch NJ. New expression profiles of voltage-gated ion channels in arteries exposed to high blood pressure. Microcirculation 9: 243-257, 2002.

36. Csala M, Banhegyi G, and Benedetti A. Endoplasmic reticulum: a metabolic compartment. FEBS Lett 580: 2160 2165, 2006.

37. Cui Y, Tran S, Tinker A, and Clapp LH. The molecular composition of K(ATP) channels in human pulmonary artery smooth muscle cells and their modulation by growth. Am J Respir Cell Mol Biol 26: 135-143, 2002.

38. Dart C and Standen NB. Activation of ATP-dependent K+ channels by hypoxia in smooth muscle cells isolated from the pig coronary artery. J Physiol 483 (Pt 1): 29-39, 1995.

39. Daut J, Maier-Rudolph W, von Beckerath N, Mehrke G, Gunther K, and Goedel-Meinen L. Hypoxic dilation of coronary arteries is mediated by ATP-sensitive potassium channels. Science 247: 1341-1344, 1990.

40. DiChiara TJ and Reinhart PH. Redox modulation of hslo Ca2 + -activated K + channels. J Neurosci 17: 4942-4955, 1997.

41. Dietrich A, Mederos y Schnitzler M, Kalwa H, Storch U, and Gudermann T. Functional characterization and physiological relevance of the TRPC3/6/7 subfamily of cation channels. Naunyn Schmiedebergs Arch Pharmacol 371: 257-265, 2005.

42. Doi S, Damron DS, Ogawa K, Tanaka S, Horibe M, and Murray PA. $\mathrm{K}(+)$ channel inhibition, calcium signaling, and vasomotor tone in canine pulmonary artery smooth muscle. Am J Physiol Lung Cell Mol Physiol 279: L242L251, 2000.

43. Dong DL, Yue P, Yang BF, and Wang WH. Hydrogen peroxide stimulates the $\mathrm{Ca}(2+)$-activated big-conductance $\mathrm{K}$ channels (BK) through cGMP signaling pathway in cultured human endothelial cells. Cell Physiol Biochem 22: 119-126, 2008.

44. Dong Q, Zhao N, Xia CK, Du LL, Fu XX, and Du YM. Hypoxia induces voltage-gated $\mathrm{K}+(\mathrm{Kv})$ channel expression in pulmonary arterial smooth muscle cells through hypoxia-inducible factor-1 (HIF-1). Bosn J Basic Med 12: 158-163, 2012.

45. Dospinescu C, Widmer H, Rowe I, Wainwright C, and Cruickshank SF. Hypoxia sensitivity of a voltage-gated potassium current in porcine intrapulmonary vein smooth muscle cells. Am J Physiol Lung Cell Mol Physiol 303: L476-L486, 2012.

46. Elsner M, Gehrmann W, and Lenzen S. Peroxisomegenerated hydrogen peroxide as important mediator of lipotoxicity in insulin-producing cells. Diabetes 60: 200208, 2011.

47. Evans AM, Osipenko ON, and Gurney AM. Properties of a novel $\mathrm{K}+$ current that is active at resting potential in 
rabbit pulmonary artery smooth muscle cells. $J$ Physiol 496 (Pt 2): 407-420, 1996.

48. Franco-Obregon A and Lopez-Barneo J. Differential oxygen sensitivity of calcium channels in rabbit smooth muscle cells of conduit and resistance pulmonary arteries. J Physiol 491 (Pt 2): 511-518, 1996.

49. Franco-Obregon A and Lopez-Barneo J. Low PO2 inhibits calcium channel activity in arterial smooth muscle cells. Am J Physiol 271: H2290-H2299, 1996.

50. Fuchs B, Dietrich A, Gudermann T, Kalwa H, Grimminger F, and Weissmann N. The role of classical transient receptor potential channels in the regulation of hypoxic pulmonary vasoconstriction. Adv Exp Med Biol 661: 187200, 2010.

51. Fuchs B, Rupp M, Ghofrani HA, Schermuly RT, Seeger W, Grimminger F, Gudermann T, Dietrich A, and Weissmann N. Diacylglycerol regulates acute hypoxic pulmonary vasoconstriction via TRPC6. Respir Res 12: 20, 2011.

52. Fuchs B, Sommer N, Dietrich A, Schermuly RT, Ghofrani HA, Grimminger F, Seeger W, Gudermann T, and Weissmann N. Redox signaling and reactive oxygen species in hypoxic pulmonary vasoconstriction. Respir Physiol Neurobiol 174: 282-291, 2010.

53. Gardener MJ, Johnson IT, Burnham MP, Edwards G, Heagerty AM, and Weston AH. Functional evidence of a role for two-pore domain potassium channels in rat mesenteric and pulmonary arteries. Br J Pharmacol 142: 192202, 2004.

54. Gill JS, McKenna WJ, and Camm AJ. Free radicals irreversibly decrease $\mathrm{Ca} 2+$ currents in isolated guinea-pig ventricular myocytes. Eur J Pharmacol 292: 337-340, 1995.

55. Goldhaber JI, Ji S, Lamp ST, and Weiss JN. Effects of exogenous free radicals on electromechanical function and metabolism in isolated rabbit and guinea pig ventricle. Implications for ischemia and reperfusion injury. J Clin Invest 83: 1800-1809, 1989.

56. Gollasch M, Lohn M, Furstenau M, Nelson MT, Luft FC, and Haller $\mathrm{H}$. $\mathrm{Ca} 2+$ channels, $\mathrm{Ca} 2+$ sparks, and regulation of arterial smooth muscle function. Z Kardiol 89 Suppl 2: 15-19, 2000.

57. Gonczi M, Szentandrassy N, Johnson IT, Heagerty AM, and Weston AH. Investigation of the role of TASK-2 channels in rat pulmonary arteries; pharmacological and functional studies following RNA interference procedures. Br J Pharmacol 147: 496-505, 2006.

58. Gong L, Gao TM, Huang H, and Tong Z. Redox modulation of large conductance calcium-activated potassium channels in CA1 pyramidal neurons from adult rat hippocampus. Neurosci Lett 286: 191-194, 2000.

59. Gonzalez C, Baez-Nieto D, Valencia I, Oyarzun I, Rojas P, Naranjo D, and Latorre R. K(+) channels: functionstructural overview. Compr Physiol 2: 2087-2149, 2012.

60. Groschner K, Rosker C, and Lukas M. Role of TRP channels in oxidative stress. Novartis Found Symp 258: 222-230; discussion 231-225, 263-226, 2004.

61. Guo L, Qiu Z, Zhang L, Chen S, and Zhu D. Hypoxia suppresses Kv 2.1 channel expression through endogenous 15 -hydroxyeicosatetraenoic acid in rat pulmonary artery. $J$ Physiol Sci 60: 373-381, 2010.

62. Gurney A and Manoury B. Two-pore potassium channels in the cardiovascular system. Eur Biophys J 38: 305-318, 2009.

63. Heginbotham L, Lu Z, Abramson T, and MacKinnon R. Mutations in the $\mathrm{K}+$ channel signature sequence. Biophys J 66: 1061-1067, 1994.
64. Hidalgo C and Donoso P. Crosstalk between calcium and redox signaling: from molecular mechanisms to health implications. Antioxid Redox Signal 10: 1275-1312, 2008.

65. Hilenski LL, Clempus RE, Quinn MT, Lambeth JD, and Griendling KK. Distinct subcellular localizations of Nox1 and Nox4 in vascular smooth muscle cells. Arterioscler Thromb Vasc Biol 24: 677-683, 2004.

66. Hillier SC, Graham JA, Hanger CC, Godbey PS, Glenny RW, and Wagner WW, Jr. Hypoxic vasoconstriction in pulmonary arterioles and venules. J Appl Physiol 82: 1084-1090, 1997.

67. Himpens B, De Smedt H, Droogmans G, and Casteels R. Differences in regulation between nuclear and cytoplasmic $\mathrm{Ca} 2+$ in cultured smooth muscle cells. Am J Physiol 263: C95-C105, 1992.

68. Hirenallur SD, Haworth ST, Leming JT, Chang J, Hernandez G, Gordon JB, and Rusch NJ. Upregulation of vascular calcium channels in neonatal piglets with hypoxia-induced pulmonary hypertension. Am J Physiol Lung Cell Mol Physiol 295: L915-L924, 2008.

69. Hool LC and Corry B. Redox control of calcium channels: from mechanisms to therapeutic opportunities. Antioxid Redox Signal 9: 409-435, 2007.

70. Hudasek K, Brown ST, and Fearon IM. H2O2 regulates recombinant $\mathrm{Ca} 2+$ channel alpha1C subunits but does not mediate their sensitivity to acute hypoxia. Biochem Biophys Res Commun 318: 135-141, 2004.

71. Ishiguro M, Wellman TL, Honda A, Russell SR, Tranmer $\mathrm{BI}$, and Wellman GC. Emergence of a R-type $\mathrm{Ca} 2+$ channel $(\mathrm{CaV} 2.3)$ contributes to cerebral artery constriction after subarachnoid hemorrhage. Circ Res 96: 419-426, 2005.

72. Ishii M, Shimizu S, Hara Y, Hagiwara T, Miyazaki A, Mori Y, and Kiuchi Y. Intracellular-produced hydroxyl radical mediates $\mathrm{H} 2 \mathrm{O} 2$-induced $\mathrm{Ca} 2+$ influx and cell death in rat beta-cell line RIN-5F. Cell Calcium 39: 487494, 2006.

73. Jabr RI, Toland H, Gelband CH, Wang XX, and Hume JR. Prominent role of intracellular $\mathrm{Ca} 2+$ release in hypoxic vasoconstriction of canine pulmonary artery. $\mathrm{Br} J$ Pharmacol 122: 21-30, 1997.

74. Kaludercic N, Deshwal S, and Di Lisa F. Reactive oxygen species and redox compartmentalization. Front Physiol 5: 285, 2014.

75. Kaludercic N, Mialet-Perez J, Paolocci N, Parini A, and Di Lisa F. Monoamine oxidases as sources of oxidants in the heart. J Mol Cell Cardiol 73: 34-42, 2014.

76. Kilfoil PJ, Tipparaju SM, Barski OA, and Bhatnagar A. Regulation of ion channels by pyridine nucleotides. Circ Res 112: 721-741, 2013.

77. Kim Y, Lee SH, and Ho WK. Hydrogen peroxide selectively increases TREK-2 currents via myosin light chain kinases. Front Biosci 12: 1642-1650, 2007.

78. Konik EA, Han YS, and Brozovich FV. The role of pulmonary vascular contractile protein expression in pulmonary arterial hypertension. J Mol Cell Cardiol 65: 147-155, 2013.

79. Korovkina VP and England SK. Molecular diversity of vascular potassium channel isoforms. Clin Exp Pharmacol Physiol 29: 317-323, 2002.

80. Krick S, Platoshyn O, McDaniel SS, Rubin LJ, and Yuan JX. Augmented $\mathrm{K}(+)$ currents and mitochondrial membrane depolarization in pulmonary artery myocyte 
apoptosis. Am J Physiol Lung Cell Mol Physiol 281: L887-L894, 2001.

81. Krick S, Platoshyn O, Sweeney M, Kim H, and Yuan JX. Activation of $\mathrm{K}+$ channels induces apoptosis in vascular smooth muscle cells. Am J Physiol Cell Physiol 280: C970-C979, 2001.

82. Krippeit-Drews P, Kramer C, Welker S, Lang F, Ammon $\mathrm{HP}$, and Drews G. Interference of $\mathrm{H} 2 \mathrm{O} 2$ with stimulussecretion coupling in mouse pancreatic beta-cells. $J$ Physiol 514 (Pt 2): 471-481, 1999.

83. Kuo IY, Wolfle SE, and Hill CE. T-type calcium channels and vascular function: the new kid on the block? J Physiol 589: 783-795, 2011.

84. Lee S, Park M, So I, and Earm YE. NADH and NAD modulates $\mathrm{Ca}(2+)$-activated $\mathrm{K}+$ channels in small pulmonary arterial smooth muscle cells of the rabbit. Pflugers Arch 427: 378-380, 1994.

85. Lee YM, Kim BJ, Chun YS, So I, Choi H, Kim MS, and Park JW. NOX4 as an oxygen sensor to regulate TASK-1 activity. Cell Signal 18: 499-507, 2006.

86. Li S, Tabar SS, Malec V, Eul BG, Klepetko W, Weissmann N, Grimminger F, Seeger W, Rose F, and Hanze J. NOX4 regulates ROS levels under normoxic and hypoxic conditions, triggers proliferation, and inhibits apoptosis in pulmonary artery adventitial fibroblasts. Antioxid Redox Signal 10: 1687-1698, 2008.

87. Link TE, Murakami K, Beem-Miller M, Tranmer BI, and Wellman GC. Oxyhemoglobin-induced expression of Rtype $\mathrm{Ca} 2+$ channels in cerebral arteries. Stroke 39: $2122-$ 2128, 2008.

88. Liu Y, Terata K, Chai Q, Li H, Kleinman LH, and Gutterman DD. Peroxynitrite inhibits $\mathrm{Ca} 2+$-activated $\mathrm{K}+$ channel activity in smooth muscle of human coronary arterioles. Circ Res 91: 1070-1076, 2002.

89. Lu W, Wang J, Shimoda LA, and Sylvester JT. Differences in STIM1 and TRPC expression in proximal and distal pulmonary arterial smooth muscle are associated with differences in $\mathrm{Ca} 2+$ responses to hypoxia. Am J Physiol Lung Cell Mol Physiol 295: L104-L113, 2008.

90. Lukyanov KA and Belousov VV. Genetically encoded fluorescent redox sensors. Biochim Biophys Acta 1840: 745-756, 2014.

91. Lv Y, Tang LL, Wei JK, Xu XF, Gu W, Fu LC, Zhang LY, and Du LZ. Decreased Kv1.5 expression in intrauterine growth retardation rats with exaggerated pulmonary hypertension. Am J Physiol Lung Cell Mol Physiol 305: L856-L865, 2013.

92. Maingret F, Honore E, Lazdunski M, and Patel AJ. Molecular basis of the voltage-dependent gating of TREK-1, a mechano-sensitive $\mathrm{K}(+)$ channel. Biochem Biophys Res Commun 292: 339-346, 2002.

93. Malczyk M, Veith C, Fuchs B, Hofmann K, Storch U, Schermuly RT, Witzenrath M, Ahlbrecht K, Fecher-Trost C, Flockerzi V, Ghofrani HA, Grimminger F, Seeger W, Gudermann T, Dietrich A, and Weissmann N. Classical transient receptor potential channel 1 in hypoxia-induced pulmonary hypertension. Am J Respir Crit Care Med 188: 1451-1459, 2013.

94. Mandegar M, Remillard CV, and Yuan JX. Ion channels in pulmonary arterial hypertension. Prog Cardiovasc Dis 45: 81-114, 2002.

95. Martinac B. Mechanosensitive ion channels: molecules of mechanotransduction. J Cell Sci 117: 2449-2460, 2004.
96. Mauban JR, Remillard CV, and Yuan JX. Hypoxic pulmonary vasoconstriction: role of ion channels. J Appl Physiol 98: 415-420, 2005.

97. McMurtry IF, Davidson AB, Reeves JT, and Grover RF. Inhibition of hypoxic pulmonary vasoconstriction by calcium antagonists in isolated rat lungs. Circ Res 38: 99104, 1976.

98. Mikami A, Imoto K, Tanabe T, Niidome T, Mori Y, Takeshima $H$, Narumiya $S$, and Numa S. Primary structure and functional expression of the cardiac dihydropyridine-sensitive calcium channel. Nature 340: 230-233, 1989.

99. Miller FJ, Jr., Filali M, Huss GJ, Stanic B, Chamseddine A, Barna TJ, and Lamb FS. Cytokine activation of nuclear factor kappa B in vascular smooth muscle cells requires signaling endosomes containing Nox 1 and $\mathrm{ClC}-3$. Circ Res 101: 663-671, 2007.

100. Mishina NM, Tyurin-Kuzmin PA, Markvicheva KN, Vorotnikov AV, Tkachuk VA, Laketa V, Schultz C, Lukyanov S, and Belousov VV. Does cellular hydrogen peroxide diffuse or act locally? Antioxid Redox Signal 14: 1-7, 2011.

101. Mittal M, Gu XQ, Pak O, Pamenter ME, Haag D, Fuchs DB, Schermuly RT, Ghofrani HA, Brandes RP, Seeger W, Grimminger F, Haddad GG, and Weissmann N. Hypoxia induces $\mathrm{Kv}$ channel current inhibition by increased NADPH oxidase-derived reactive oxygen species. Free Radic Biol Med 52: 1033-1042, 2012.

102. Moudgil R, Michelakis ED, and Archer SL. The role of $\mathrm{k}+$ channels in determining pulmonary vascular tone, oxygen sensing, cell proliferation, and apoptosis: implications in hypoxic pulmonary vasoconstriction and pulmonary arterial hypertension. Microcirculation 13: 615-632, 2006.

103. Mungai PT, Waypa GB, Jairaman A, Prakriya M, Dokic D, Ball MK, and Schumacker PT. Hypoxia triggers AMPK activation through reactive oxygen species-mediated activation of calcium release-activated calcium channels. $\mathrm{Mol}$ Cell Biol 31: 3531-3545, 2011.

104. Nelson MT. $\mathrm{Ca}(2+)$-activated potassium channels and ATP-sensitive potassium channels as modulators of vascular tone. Trends Cardiovasc Med 3: 54-60, 1993.

105. Nelson MT and Quayle JM. Physiological roles and properties of potassium channels in arterial smooth muscle. Am J Physiol 268: C799-C822, 1995.

106. Nilius B, Viana F, and Droogmans G. Ion channels in vascular endothelium. Annu Rev Physiol 59: 145-170, 1997.

107. Olschewski A, Hong Z, Nelson DP, and Weir EK. Graded response of $\mathrm{K}+$ current, membrane potential, and $[\mathrm{Ca} 2+] \mathrm{i}$ to hypoxia in pulmonary arterial smooth muscle. Am J Physiol Lung Cell Mol Physiol 283: L1143-L1150, 2002.

108. Olschewski A, Li Y, Tang B, Hanze J, Eul B, Bohle RM, Wilhelm J, Morty RE, Brau ME, Weir EK, Kwapiszewska G, Klepetko W, Seeger W, and Olschewski H. Impact of TASK-1 in human pulmonary artery smooth muscle cells. Circ Res 98: 1072-1080, 2006.

109. Olschewski A and Weir EK. Redox regulation of ion channels in the pulmonary circulation. Antioxid Redox Signal 22: 465-485, 2015.

110. Owsianik G, Talavera K, Voets T, and Nilius B. Permeation and selectivity of TRP channels. Annu Rev Physiol 68: 685-717, 2006. 
111. Pak O, Sommer N, Hoeres T, Bakr A, Waisbrod S, Sydykov A, Haag D, Esfandiary A, Kojonazarov B, Veit F, Fuchs B, Weisel FC, Hecker M, Schermuly RT, Grimminger F, Ghofrani HA, Seeger W, and Weissmann N. Mitochondrial hyperpolarization in pulmonary vascular remodeling. Mitochondrial uncoupling protein deficiency as disease model. Am J Respir Cell Mol Biol 49: 358-367, 2013.

112. Papreck JR, Martin EA, Lazzarini P, Kang D, and Kim D. Modulation of K2P3.1 (TASK-1), K2P9.1 (TASK-3), and TASK-1/3 heteromer by reactive oxygen species. Pflugers Arch 464: 471-480, 2012.

113. Park MK, Lee SH, Lee SJ, Ho WK, and Earm YE. Different modulation of Ca-activated $\mathrm{K}$ channels by the intracellular redox potential in pulmonary and ear arterial smooth muscle cells of the rabbit. Pflugers Arch 430: 308314, 1995.

114. Park SJ, Chun YS, Park KS, Kim SJ, Choi SO, Kim HL, and Park JW. Identification of subdomains in NADPH oxidase-4 critical for the oxygen-dependent regulation of TASK-1 K+ channels. Am J Physiol Cell Physiol 297: C855-C864, 2009.

115. Pedersen SF, Owsianik G, and Nilius B. TRP channels: an overview. Cell Calcium 38: 233-252, 2005.

116. Peers C, Scragg JL, Boyle JP, Fearon IM, Taylor SC, Green KN, Webster NJ, Ramsden M, and Pearson HA. A central role for ROS in the functional remodelling of Ltype $\mathrm{Ca} 2+$ channels by hypoxia. Philos Trans $R$ Soc Lond B Biol Sci 360: 2247-2254, 2005.

117. Plant LD, Rajan S, and Goldstein SA. K2P channels and their protein partners. Curr Opin Neurobiol 15: 326-333, 2005.

118. Platoshyn O, Golovina VA, Bailey CL, Limsuwan A, Krick S, Juhaszova M, Seiden JE, Rubin LJ, and Yuan JX. Sustained membrane depolarization and pulmonary artery smooth muscle cell proliferation. Am J Physiol Cell Physiol 279: C1540-C1549, 2000.

119. Platoshyn O, Yu Y, Golovina VA, McDaniel SS, Krick S, Li L, Wang JY, Rubin LJ, and Yuan JX. Chronic hypoxia decreases $\mathrm{K}(\mathrm{V})$ channel expression and function in pulmonary artery myocytes. Am J Physiol Lung Cell Mol Physiol 280: L801-L812, 2001.

120. Porter VA, Rhodes MT, Reeve HL, and Cornfield DN. Oxygen-induced fetal pulmonary vasodilation is mediated by intracellular calcium activation of $\mathrm{K}(\mathrm{Ca})$ channels. $\mathrm{Am}$ J Physiol Lung Cell Mol Physiol 281: L1379-L1385, 2001.

121. Post JM, Gelband $\mathrm{CH}$, and Hume JR. $[\mathrm{Ca} 2+]$ i inhibition of $\mathrm{K}+$ channels in canine pulmonary artery. Novel mechanism for hypoxia-induced membrane depolarization. Circ Res 77: 131-139, 1995.

122. Post JM, Hume JR, Archer SL, and Weir EK. Direct role for potassium channel inhibition in hypoxic pulmonary vasoconstriction. Am J Physiol 262: C882-C890, 1992.

123. Poteser M, Graziani A, Rosker C, Eder P, Derler I, Kahr H, Zhu MX, Romanin C, and Groschner K. TRPC3 and TRPC4 associate to form a redox-sensitive cation channel. Evidence for expression of native TRPC3-TRPC4 heteromeric channels in endothelial cells. J Biol Chem 281: 13588-13595, 2006.

124. Reeve HL, Michelakis E, Nelson DP, Weir EK, and Archer SL. Alterations in a redox oxygen sensing mecha- nism in chronic hypoxia. J Appl Physiol 90: 2249-2256, 2001.

125. Reeve HL, Weir EK, Archer SL, and Cornfield DN. A maturational shift in pulmonary $\mathrm{K}+$ channels, from $\mathrm{Ca} 2+$ sensitive to voltage dependent. Am J Physiol 275: L1019L1025, 1998.

126. Rhodes MT, Porter VA, Saqueton CB, Herron JM, Resnik ER, and Cornfield DN. Pulmonary vascular response to normoxia and $\mathrm{K}(\mathrm{Ca})$ channel activity is developmentally regulated. Am J Physiol Lung Cell Mol Physiol 280: L1250-L1257, 2001.

127. Robbins CA and Tempel BL. Kv1.1 and Kv1.2: similar channels, different seizure models. Epilepsia 53 Suppl 1: 134-141, 2012.

128. Robertson BE, Kozlowski RZ, and Nye PC. Opposing actions of tolbutamide and glibenclamide on hypoxic pulmonary vasoconstriction. Comp Biochem Physiol C 102: 459-462, 1992.

129. Rodman DM, Reese K, Harral J, Fouty B, Wu S, West J, Hoedt-Miller M, Tada Y, Li KX, Cool C, Fagan K, and Cribbs L. Low-voltage-activated (T-type) calcium channels control proliferation of human pulmonary artery myocytes. Circ Res 96: 864-872, 2005.

130. Roth M, Rupp M, Hofmann S, Mittal M, Fuchs B, Sommer N, Parajuli N, Quanz K, Schubert D, Dony E, Schermuly RT, Ghofrani HA, Sausbier U, Rutschmann K, Wilhelm S, Seeger W, Ruth P, Grimminger F, Sausbier M, and Weissmann $\mathrm{N}$. Heme oxygenase-2 and largeconductance $\mathrm{Ca} 2+$-activated $\mathrm{K}+$ channels: lung vascular effects of hypoxia. Am J Respir Crit Care Med 180: 353364, 2009.

131. Sahoo N, Schonherr R, Hoshi T, and Heinemann SH. Cysteines control the $\mathrm{N}$ - and C-linker-dependent gating of KCNH1 potassium channels. Biochim Biophys Acta 1818: 1187-1195, 2012.

132. Sanders KM and Koh SD. Two-pore-domain potassium channels in smooth muscles: new components of myogenic regulation. J Physiol 570: 37-43, 2006.

133. Schumacker PT. Lung cell hypoxia: role of mitochondrial reactive oxygen species signaling in triggering responses. Proc Am Thorac Soc 8: 477-484, 2011.

134. Snetkov VA, Knock GA, Baxter L, Thomas GD, Ward JP, and Aaronson PI. Mechanisms of the prostaglandin F2alpha-induced rise in $[\mathrm{Ca} 2+]$ i in rat intrapulmonary arteries. J Physiol 571: 147-163, 2006.

135. Sobey CG, Heistad DD, and Faraci FM. Mechanisms of bradykinin-induced cerebral vasodilatation in rats. Evidence that reactive oxygen species activate $\mathrm{K}+$ channels. Stroke 28: 2290-2294; discussion 2295, 1997.

136. Sommer N, Dietrich A, Schermuly RT, Ghofrani HA, Gudermann T, Schulz R, Seeger W, Grimminger F, and Weissmann N. Regulation of hypoxic pulmonary vasoconstriction: basic mechanisms. Eur Respir J 32: 16391651, 2008.

137. Stone JR and Yang S. Hydrogen peroxide: a signaling messenger. Antioxid Redox Signal 8: 243-270, 2006.

138. Sylvester JT, Shimoda LA, Aaronson PI, and Ward JP. Hypoxic pulmonary vasoconstriction. Physiol Rev 92: 367-520, 2012.

139. Takahashi N, Mizuno Y, Kozai D, Yamamoto S, Kiyonaka S, Shibata T, Uchida K, and Mori Y. Molecular characterization of TRPA1 channel activation by cysteine-reactive inflammatory mediators. Channels 2: 287-298, 2008. 
140. Talley EM, Solorzano G, Lei Q, Kim D, and Bayliss DA. Cns distribution of members of the two-pore-domain (KCNK) potassium channel family. J Neurosci 21: 74917505, 2001.

141. Tang C, To WK, Meng F, Wang Y, and Gu Y. A role for receptor-operated $\mathrm{Ca} 2+$ entry in human pulmonary artery smooth muscle cells in response to hypoxia. Physiol Res 59: 909-918, 2010.

142. Tang K, Li X, Zheng MQ, and Rozanski GJ. Role of apoptosis signal-regulating kinase-1-c-Jun NH2-terminal kinase-p38 signaling in voltage-gated $\mathrm{K}+$ channel remodeling of the failing heart: regulation by thioredoxin. Antioxid Redox Signal 14: 25-35, 2011.

143. Tang XD, Daggett H, Hanner M, Garcia ML, McManus OB, Brot N, Weissbach H, Heinemann SH, and Hoshi T. Oxidative regulation of large conductance calcium-activated potassium channels. J Gen Physiol 117: 253-274, 2001.

144. Thengchaisri $\mathrm{N}$ and Kuo L. Hydrogen peroxide induces endothelium-dependent and -independent coronary arteriolar dilation: role of cyclooxygenase and potassium channels. Am J Physiol Heart Circ Physiol 285: H2255H2263, 2003.

145. Turner PJ and Buckler KJ. Oxygen and mitochondrial inhibitors modulate both monomeric and heteromeric TASK-1 and TASK-3 channels in mouse carotid body type-1 cells. J Physiol 591: 5977-5998, 2013.

146. Wan J, Yamamura A, Zimnicka AM, Voiriot G, Smith KA, Tang H, Ayon RJ, Choudhury MS, Ko EA, Wang J, Wang C, Makino A, and Yuan JX. Chronic hypoxia selectively enhances L- and T-type voltage-dependent $\mathrm{Ca} 2+$ channel activity in pulmonary artery by upregulating Cav1.2 and Cav3.2. Am J Physiol Lung Cell Mol Physiol 305: L154-L164, 2013.

147. Wang J, Juhaszova M, Rubin LJ, and Yuan XJ. Hypoxia inhibits gene expression of voltage-gated $\mathrm{K}+$ channel alpha subunits in pulmonary artery smooth muscle cells. $J$ Clin Invest 100: 2347-2353, 1997.

148. Wang J, Shimoda LA, Weigand L, Wang W, Sun D, and Sylvester JT. Acute hypoxia increases intracellular $[\mathrm{Ca} 2+]$ in pulmonary arterial smooth muscle by enhancing capacitative Ca2 + entry. Am J Physiol Lung Cell Mol Physiol 288: L1059-L1069, 2005.

149. Wang J, Weigand L, Wang W, Sylvester JT, and Shimoda LA. Chronic hypoxia inhibits Kv channel gene expression in rat distal pulmonary artery. Am J Physiol Lung Cell Mol Physiol 288: L1049-L1058, 2005.

150. Wang Y, Deng X, Hewavitharana T, Soboloff J, and Gill DL. Stim, ORAI and TRPC channels in the control of calcium entry signals in smooth muscle. Clin Exp Pharmacol Physiol 35: 1127-1133, 2008.

151. Wang YX and Zheng YM. Role of ROS signaling in differential hypoxic $\mathrm{Ca} 2+$ and contractile responses in pulmonary and systemic vascular smooth muscle cells. Respir Physiol Neurobiol 174: 192-200, 2010.

152. Waypa GB, Guzy R, Mungai PT, Mack MM, Marks JD, Roe MW, and Schumacker PT. Increases in mitochondrial reactive oxygen species trigger hypoxia-induced calcium responses in pulmonary artery smooth muscle cells. Circ Res 99: 970-978, 2006.

153. Waypa GB, Marks JD, Guzy R, Mungai PT, Schriewer J, Dokic D, and Schumacker PT. Hypoxia triggers subcellular compartmental redox signaling in vascular smooth muscle cells. Circ Res 106: 526-535, 2010.
154. Wei EP, Kontos HA, and Beckman JS. Mechanisms of cerebral vasodilation by superoxide, hydrogen peroxide, and peroxynitrite. Am J Physiol 271: H1262-H1266, 1996.

155. Weigand L, Foxson J, Wang J, Shimoda LA, and Sylvester JT. Inhibition of hypoxic pulmonary vasoconstriction by antagonists of store-operated $\mathrm{Ca} 2+$ and nonselective cation channels. Am J Physiol Lung Cell Mol Physiol 289: L5-L13, 2005.

156. Weir EK and Archer SL. Counterpoint: hypoxic pulmonary vasoconstriction is not mediated by increased production of reactive oxygen species. J Appl Physiol 101: 995-998; discussion 998, 2006.

157. Weir EK and Archer SL. The mechanism of acute hypoxic pulmonary vasoconstriction: the tale of two channels. FASEB J 9: 183-189, 1995.

158. Weir EK, Cabrera JA, Mahapatra S, Peterson DA, and Hong Z. The role of ion channels in hypoxic pulmonary vasoconstriction. Adv Exp Med Biol 661: 3-14, 2010.

159. Weir EK, Lopez-Barneo J, Buckler KJ, and Archer SL. Acute oxygen-sensing mechanisms. N Engl J Med 353: 2042-2055, 2005.

160. Weir EK and Olschewski A. Role of ion channels in acute and chronic responses of the pulmonary vasculature to hypoxia. Cardiovasc Res 71: 630-641, 2006.

161. Weir EK, Wyatt CN, Reeve HL, Huang J, Archer SL, and Peers C. Diphenyleneiodonium inhibits both potassium and calcium currents in isolated pulmonary artery smooth muscle cells. J Appl Physiol 76: 2611-2615, 1994.

162. Weissmann N, Dietrich A, Fuchs B, Kalwa H, Ay M, Dumitrascu R, Olschewski A, Storch U, Mederos y Schnitzler M, Ghofrani HA, Schermuly RT, Pinkenburg O, Seeger W, Grimminger F, and Gudermann T. Classical transient receptor potential channel 6 (TRPC6) is essential for hypoxic pulmonary vasoconstriction and alveolar gas exchange. Proc Natl Acad Sci U S A 103: 19093-19098, 2006.

163. Weissmann N, Sommer N, Schermuly RT, Ghofrani HA, Seeger W, and Grimminger F. Oxygen sensors in hypoxic pulmonary vasoconstriction. Cardiovasc Res 71: 620-629, 2006.

164. Weissmann N, Sydykov A, Kalwa H, Storch U, Fuchs B, Mederos y Schnitzler M, Brandes RP, Grimminger F, Meissner M, Freichel M, Offermanns S, Veit F, Pak O, Krause KH, Schermuly RT, Brewer AC, Schmidt HH, Seeger W, Shah AM, Gudermann T, Ghofrani HA, and Dietrich A. Activation of TRPC6 channels is essential for lung ischaemia-reperfusion induced oedema in mice. Nat Commun 3: 649, 2012.

165. Weissmann N, Winterhalder S, Nollen M, Voswinckel R, Quanz K, Ghofrani HA, Schermuly RT, Seeger W, and Grimminger F. NO and reactive oxygen species are involved in biphasic hypoxic vasoconstriction of isolated rabbit lungs. Am J Physiol Lung Cell Mol Physiol 280: L638-L645, 2001.

166. Weissmann N, Zeller S, Schafer RU, Turowski C, Ay M, Quanz K, Ghofrani HA, Schermuly RT, Fink L, Seeger $\mathrm{W}$, and Grimminger F. Impact of mitochondria and NADPH oxidases on acute and sustained hypoxic pulmonary vasoconstriction. Am J Respir Cell Mol Biol 34: 505-513, 2006.

167. Xiong Z and Sperelakis N. Regulation of L-type calcium channels of vascular smooth muscle cells. J Mol Cell Cardiol 27: 75-91, 1995. 
168. Yang Q, Underwood MJ, and He GW. Calcium-activated potassium channels in vasculature in response to ischemia-reperfusion. J Cardiovasc Pharmacol 59: 109-115, 2012.

169. Yoo HY and Kim SJ. Disappearance of hypoxic pulmonary vasoconstriction and o2-sensitive nonselective cationic current in arterial myocytes of rats under ambient hypoxia. Korean J Physiol Pharmacol 17: 463-468, 2013.

170. Yoshida T, Inoue R, Morii T, Takahashi N, Yamamoto S, Hara Y, Tominaga M, Shimizu S, Sato Y, and Mori Y. Nitric oxide activates TRP channels by cysteine Snitrosylation. Nat Chem Biol 2: 596-607, 2006.

171. Yuan XJ. Voltage-gated $\mathrm{K}+$ currents regulate resting membrane potential and $[\mathrm{Ca} 2+] \mathrm{i}$ in pulmonary arterial myocytes. Circ Res 77: 370-378, 1995.

172. Yuan XJ, Goldman WF, Tod ML, Rubin LJ, and Blaustein MP. Hypoxia reduces potassium currents in cultured rat pulmonary but not mesenteric arterial myocytes. Am J Physiol 264: L116-L123, 1993.

173. Yuan XJ, Wang J, Juhaszova M, Golovina VA, and Rubin LJ. Molecular basis and function of voltage-gated $\mathrm{K}+$ channels in pulmonary arterial smooth muscle cells. Am J Physiol 274: L621-L635, 1998.

174. Zhou $\mathrm{C}$ and Wu S. T-type calcium channels in pulmonary vascular endothelium. Microcirculation 13: 645-656, 2006.

175. Zima AV and Blatter LA. Redox regulation of cardiac calcium channels and transporters. Cardiovasc Res 71: 310-321, 2006.

Address correspondence to: Dr. Norbert Weissmann

Excellence Cluster Cardiopulmonary System (ECCPS) Universities of Giessen and Marburg Lung Center German Center for Lung Research (DZL) Aulweg 130

Giessen D-35392

Germany

E-mail: norbert.weissmann@innere.med.uni-giessen.de

Date of first submission to ARS Central, December 16, 2014; date of acceptance, December 23, 2014.

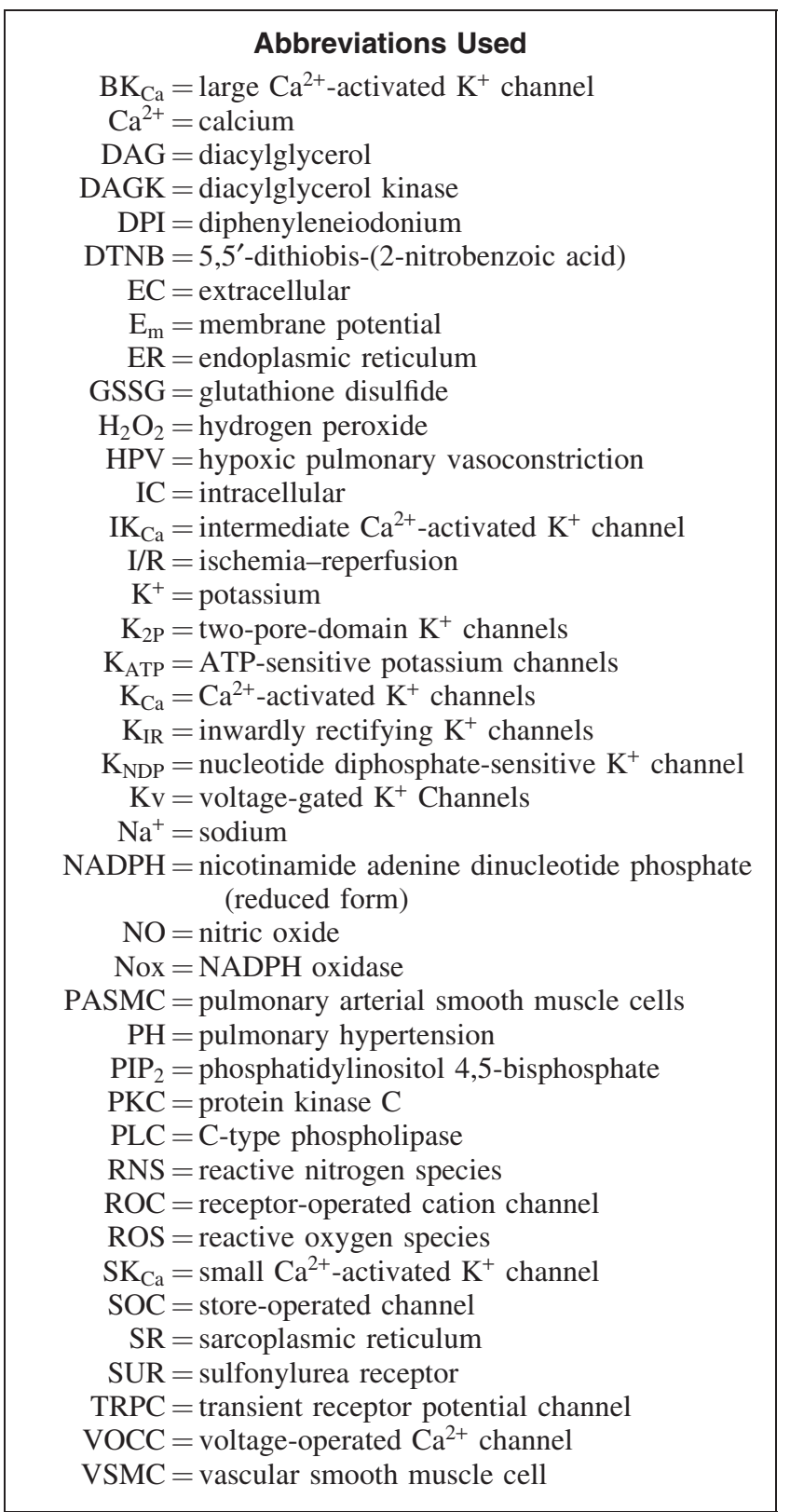

